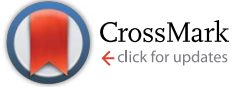

Cite this: J. Mater. Chem. A, 2016, 4, 16272

Received 23rd June 2016

Accepted 9th September 2016

DOI: $10.1039 / c 6 t a 05304 a$

www.rsc.org/MaterialsA

\section{Recent progress in electrocatalysts with mesoporous structures for application in polymer electrolyte membrane fuel cells}

\begin{abstract}
Wei $\mathrm{Xu}^{\mathrm{ab}}$ Zucheng $\mathrm{Wu}^{\mathrm{b}}$ and Shanwen Tao*ac
Recently mesoporous materials have drawn great attention in fuel cell related applications, such as preparation of polymer electrolyte membranes and catalysts, hydrogen storage and purification. In this mini-review, we focus on recent developments in mesoporous electrocatalysts for polymer electrolyte membrane fuel cells, including metallic and metal-free catalysts for use as either anode or cathode catalysts. Mesoporous Pt-based metals have been synthesized as anode catalysts with improved activity and durability. Mesoporous carbons together with other inorganic materials are better supporting materials than conventional carbon black, which have a large surface area, high porosity and synergistic effect with metal particles. Pt supported on these materials has a small particle size, uniform distribution and good access to fuels, which performs better as fuel cell catalysts than commercial Pt/C. Some efforts such as further improvement in the conductivity and chemical stability of mesoporous carbon by chemical doping are stated. Moreover, metal free cathode catalysts based on heteroatom modified mesoporous carbon are also summarized.
\end{abstract}

\section{Introduction}

Polymer electrolyte membrane fuel cells (PEMFCs) based on either a proton exchange membrane (acidic conditions) or an anion exchange membrane (alkaline conditions) can use a wide range of renewable resources such as hydrogen gas, methanol, ethanol, formic acid, ammonia, hydrazine, urea, etc. as fuels..$^{1-6}$ They demonstrate outstanding energy density among the electrochemical energy conversion and storage systems, which is about 5 times larger than that for current Li-ion batteries. ${ }^{7}$ Due to the diversity of energy resources and high energy density, PEMFCs are promising for applications in vehicles, portable electronic devices and environmental technology to produce clean energy. ${ }^{1,8-10}$ The main barriers in scaling-up PEMFCs are the cost (e.g. hydrogen storage, ion exchange membrane, catalysts) and durability of the ion exchange membrane, catalysts, and flow conditions. ${ }^{11}$ According to the U.S. Department of Energy (DOE), targets of hydrogen storage capacity and fuel cell system cost are $40 \mathrm{~kg} \mathrm{~m} \mathrm{~m}^{-3}$ and $\$ 40 \mathrm{~kW}^{-1}$ respectively by $2020 .^{12,13}$ The core components of the fuel cell system are the polymer electrolyte membrane, catalyst layer and gas diffusion layer constituting the membrane electrode assembly (MEA). The

${ }^{a}$ School of Engineering, University of Warwick, Coventry CV4 7AL, UK. E-mail: S.Tao. 1@warwick.ac.uk; Fax: +44 (0)24 764 18922; Tel: +44 (o)24 76151680

${ }^{b}$ Department of Environmental Engineering, State Key Laboratory of Clean Energy Utilization, Zhejiang University, Hangzhou 310058, Zhejiang, China

'Department of Chemical Engineering, Monash University, Clayton, Victoria 3800, Australia
MEA is reported to be accounting for about $35-50 \%$ of the cost of fuel cell systems. ${ }^{13}$ As a consequence, the MEA cost needs to be reduced by $27 \%$ to achieve the target in 2020 . Another problem is fuel cell durability, which mainly comes from membrane dehydration and catalyst degradation because of poisoning, corrosion and fuel crossover. Developing new materials for MEA is a hot topic in fuel cell research to reduce cost and improve durability.

Since the ExxonMobil's M41S series of mesoporous molecular sieves ${ }^{14}$ were first reported, research on mesoporous materials has been growing for decades. Mesoporous materials are fascinating in many research areas due to their wonderful porosity features such as tunable pore diameters, high surface areas, alternative pore shape, and diverse compositions. ${ }^{15}$ Different mesoporous composites like silica-based $\left(\mathrm{SiO}_{2}, \mathrm{MCM}-\right.$ 41 and SBA-15 series), inorganic (metal oxides, carbon) and organic-inorganic (organometallics, colloids and nano-objects, coordination polymers) are developed with specific functions to meet the needs in different applications. ${ }^{15,16}$ Recently, mesoporous materials have shown excellent performance in the applications in PEMFCs. For instance, meso-silica has been used for the synthesis of ion exchange membranes by incorporating acidic functional groups such as phosphotungstic acid, phosphoric acid, sulfonated benzene, etc. ${ }^{17-20}$ The tested membrane conductivity is comparable to that of Nafion ${ }^{\circledR}$ membrane and increases with temperature up to $200{ }^{\circ} \mathrm{C}$. Moreover, the mesoporous membrane can obviously prevent the crossover of liquid fuels (e.g. methanol, ethanol). Mesoporous materials have been intensively studied in energy 
conversion technologies. ${ }^{\mathbf{1 6}}$ The mesoporous (2-50 $\mathrm{nm}$ in pore size) network can enhance the intracrystalline diffusion over orders of magnitude to improve the mass transport, compared to diffusivity in the continuous micropore $(<2 \mathrm{~nm}$ in pore size) space. ${ }^{21}$ The molecular exchange rate of materials traversing the mesoporous network is accelerated by using the pulsed field gradient (PFG) technique of nuclear magnetic resonance (NMR) for quantitative intracrystalline diffusion measurement. Details on the mass transport of mesoporous materials have been covered in excellent reviews. ${ }^{21,22}$ In the fuel cell field, conductive mesoporous materials, especially mesoporous carbon, have been intensively investigated to prepare electrocatalysts for electrodes, in order to overcome the challenge of cost and durability of the commercial Pt/C catalyst. Mesoporous structures have advantages of large specific surface area, appropriate pore sizes ( 2 to $50 \mathrm{~nm}$ ) and large pore volumes for fuel transfer and particle deposition. Thus utilization of mesoporous structures is a promising method to obtain highly stable and active catalysts for fuel cells. In the aspect of anode catalysts, strategies include direct synthesis of mesoporous Pt and Pt alloys without supports, or formation of metallic nanoparticles on mesoporous supports (e.g. carbon, metal oxides, and metal nitrides). As for the cathode, metal based catalysts with mesoporous supports and heteroatom doped mesoporous carbons as metal-free catalysts are both widely reported. Although there are a few excellent reviews about applications of mesoporous materials in wide topics of energy conversion and storage such as solar cells, fuel production, rechargeable batteries, supercapacitors and fuel cells, ${ }^{16,23-28}$ this review focuses on the recent development of mesoporous materials for fuel cell catalysts, including mesoporous Pt (and Pt alloys), metals with mesoporous supports, and metal-free mesoporous carbon catalysts.

\section{Use of mesoporous materials as anode catalysts}

Platinum-group metals are tested to be the most active catalysts toward both anode oxidation reaction and cathode reduction reaction. The challenges in using Pt catalysts are the high cost and poisoning by the oxidation intermediates like $\mathrm{CO}_{\mathrm{ads}}$ and $\mathrm{N}_{\text {ads }}{ }^{29,30}$ Numerous studies have been carried out to improve the activity and durability of noble Pt-based catalysts by doping non-noble elements (e.g. transition metals, phosphorus) and forming hollow, core-shell or mesoporous nanostructures. ${ }^{31-33}$ Research on mesoporous electrocatalysts can be basically categorized into two approaches: direct preparation of unsupported metal electrocatalysts with mesoporous structures to obtain large surface area; enhancement of the dispersion of metal particles by depositing metals on mesoporous supporting materials.

\subsection{Metallic mesoporous electrocatalysts}

Metallic mesoporous electrocatalysts (MMECs) have a much larger electrochemically active surface area (ECSA) than conventional solid catalysts. ${ }^{5}$ In addition, the porous structure with an optimal pore size can improve the mass transport of fuels. ${ }^{34}$ Consequently, related results presented by Yusuke Yamauchi show much better performances of mesoporous Pt than Pt black in methanol electrooxidation reaction under acidic conditions. ${ }^{35,36}$ The MMECs are usually synthesized via liquid crystal templating methods. A facile way of preparing metallic MMECs by using surfactants as soft-templates has received more and more attention. ${ }^{\mathbf{1 6}}$ Low molecular weight surfactants can result in large surface areas due to the small pore size, but on the other hand mass transfer of fuels to catalyst active sites will be inadequate. Large molecular weight surfactants such as triblock copolymers can lead to a large pore size by forming "cavity-crystals". Metal ions are mixed with softtemplates via surfactant self-assembly, and then reduced to nanocomposites by chemical or electrochemical reduction. Finally the nanocomposites are washed to remove the surfactant and remaining MMECs.

Bimetallic Pt alloys are common tools to achieve better activity and resistance to the poisoning of adsorbed intermediates. ${ }^{4,37}$ Due to the mesoporous structure, the performance of Pt alloys has been further improved. For methanol electrooxidation, mesoporous Pt $\left(16 \mathrm{~m}^{2} \mathrm{~g}^{-1}\right)$ and PtRu $\left(20 \mathrm{~m}^{2} \mathrm{~g}^{-1}\right)$ with a pore diameter of $\sim 10 \mathrm{~nm}$ are prepared by electrodeposition with Pluronic F127® as the surfactant. The long limit mass activities reach 2.42 and $7.52 \mathrm{~A} \mathrm{~g}^{-1}$ for $\mathrm{Pt}$ and $\mathrm{PtRu}$, which are higher than that of the commercial Pt/C catalyst $\left(2.29 \mathrm{~A} \mathrm{~g}^{-1}\right){ }^{34}$ Mesoporous PtCo nanorods with a pore diameter of 10-14 nm are electrodeposited in the interior channels of the porous membrane with metal precursors dissolved in water-ionic liquid microemulsion. ${ }^{38,39}$ The porosity of PtCo is dependent on the ratio of water to the ionic liquid, and the diameters of nanorods are in accordance with the pore size of the membrane. It is claimed that the PtCo nanorods have an ECSA of about 40-200 $\mathrm{m}^{2} \mathrm{~g}^{-1}$, and 3 times higher mass-normalized current density than commercial $\mathrm{Pt} / \mathrm{C}$ with improved poisoning tolerance. For ethanol electrooxidation, mesoporous PtRuSn prepared by the reduction of metal precursors with a non-ionic surfactant achieves an active surface area of $54 \mathrm{~m}^{2} \mathrm{~g}^{-1}$, and lowers the onset potential by about $0.1 \mathrm{~V} .^{40}$ The current density of PtRuSn in $0.5 \mathrm{M} \mathrm{H}_{2} \mathrm{SO}_{4} / 1 \mathrm{M} \mathrm{C}_{2} \mathrm{H}_{5} \mathrm{OH}$ reaches about $20 \mathrm{~A} \mathrm{~g}^{-1}$ at $0.6 \mathrm{~V} v s$. RHE. In practice, metal particles formed with a small size (usually around several $\mathrm{nm}$ ) are beneficial for larger active surface areas and better activity. ${ }^{41}$ However the pore size of MMECs does not have a similar effect to the particle size. Mesoporous PtRu with a pore size of $10 \mathrm{~nm}$ is observed to be better than that with a pore size of $3 \mathrm{~nm}$ for methanol oxidation. ${ }^{42}$ The possible reason is that methanol residence time is not sufficient owing to the poor mass transfer if the pore size is less than $3 \mathrm{~nm} .{ }^{43}$ In contrast, catalysts with a $10 \mathrm{~nm}$ pore size have greater accessibility to methanol, thus methanol can be adequately oxidized in larger pores. This indicates that the pore size of MMECs is an important factor.

\subsection{Metals supported on mesoporous materials (MSMMs)}

Another strategy of preparing mesoporous electrocatalysts for fuel cell anodes is to deposit metals on mesoporous materials. In comparison with MMECs, mesoporous catalysts for fuel cells 
are mainly focused on MSMMs according to published reports. In particular, supporting materials such as carbon black for metal catalysts have been commonly used to prepare electrodes in fuel cell fabrication. Carbon supporting materials have a large surface area and high electrical conductivity, so they can greatly improve the performance of catalysts. ${ }^{43}$ With the development of carbon supported catalysts, the loading of noble metals in fuel cells has been largely reduced. However, traditional carbon supporting materials still face some disadvantages. First, carbon black is susceptible to corrosion caused by electrochemical oxidation. ${ }^{44,45}$ Second, the size of micropores (less than $1 \mathrm{~nm}$ ) in carbon is too small to achieve sufficient mass transfer of fuel to the catalyst surface, thus limiting the activity of the catalyst. ${ }^{46,47}$ In the same way, micropores will result in a low accessible surface area to support metal deposition, so metal particles primarily reside on the outer carbon black surface. Third, carbon black is resistant to gas and liquid diffusion and does not conduct protons, leading to low catalyst utilization. Accordingly, ionomers like expensive Nafion ${ }^{\circledR}$ inks are always used to increase the three-phase boundary and facilitate transport of protons. ${ }^{48}$

In order to solve the above problems, novel supporting materials are applied with the development of advanced nanomaterials. For example, graphene, carbon nanotubes and mesoporous carbon have been used to prepare metal based catalysts for fuel cells and exhibit improved electrochemical properties due to the large surface area, high chemical stability and excellent electrical conductivity. ${ }^{49-52}$ The pore size of mesoporous materials ( 2 to $50 \mathrm{~nm}$ ) matches with those of most metal particles, leading to a high accessible surface area to support metal deposition. Besides, the relatively large pores $(>3 \mathrm{~nm})$ are able to allow fuels to contact the metal surface with long residence time, resulting in a high utilization of metals and high oxidation efficiency. Although the commercial ordered mesoporous silica (OMS) is proved to be an ideal supporting material in environment- and energy-related catalysis, the poor electrical conductivity limits its direct application in fuel cells. ${ }^{53,54}$ Based on a silica template, mesoporous carbon materials were first prepared in 1999, which had great scientific and technological importance as new electrode materials to be applied in fuel cells. ${ }^{55}$ Present research studies are mostly concentrated on ordered mesoporous carbons (OMCs).

The hard-template (e.g. SBA-15, MCM-41 and silica colloid) and soft-template (e.g. amphiphilic surfactants and triblock copolymers) approaches are two widely used synthesis methods of OMCs. In the hard-template method, pores in OMS are mixed with a carbon source (e.g. sucrose, resorcinol and formaldehyde). Then the carbonization is completed by pyrolysis at high temperature, followed by removing the silica template to obtain the OMCs. In the soft-template method, a carbon precursor (organic monomers) is polymerized with the self-assembly of a surfactant in a liquid to form a carbon-surfactant composite. After removing the surfactant, carbonization will be carried out by pyrolysis at high temperature. Schematic diagrams of the two synthesis methods are shown in Fig. $1{ }^{56}$ Both methods to make carbon based mesoporous supporting materials require a pyrolysis process (normally at $900-1000{ }^{\circ} \mathrm{C}$ under a $\mathrm{N}_{2}$ a

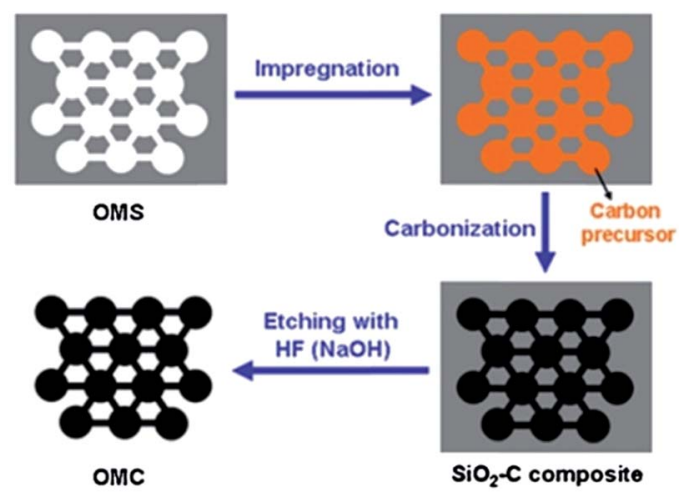

b

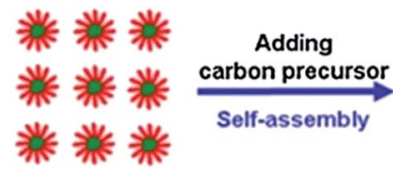

Surfactant micella
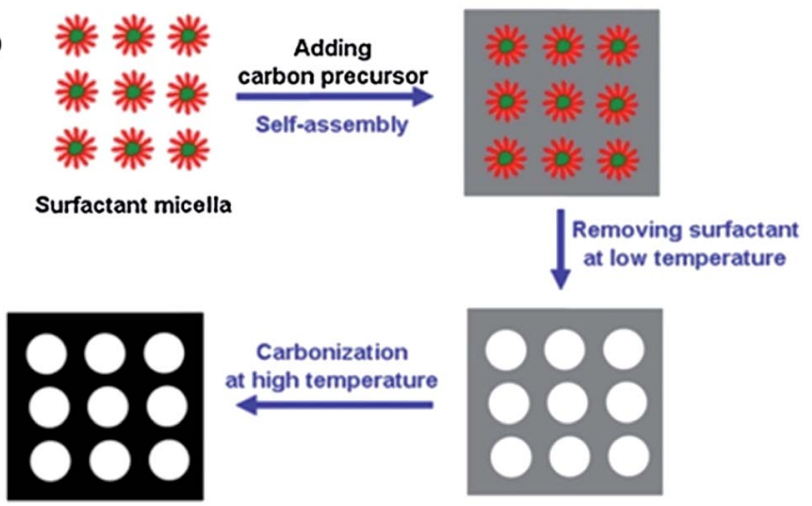

Carbonization at high temperature

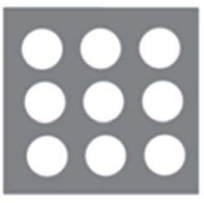

Fig. 1 Schematic diagrams of (a) hard template and (b) soft template methods to prepare mesoporous carbon. Reproduced with permission from ref. 56. Copyright 2014, Elsevier.

atmosphere) to graphitize the carbon precursor. Mesoporous carbon nanoparticles can also be prepared with glucose as the carbon precursor partially carbonized at $180^{\circ} \mathrm{C}$ for $4 \mathrm{~h}$, followed by functionalization with an amine-terminated ionic liquid. ${ }^{57}$ Finally, metal ions are reduced and deposited on OMCs to obtain MSMMs.

Until now, different kinds of MSMMs have been successfully synthesized. In Ahn et al.'s experiment, colloidal silica was used as the template and sucrose was used as the carbon source to obtain $50 \mathrm{wt} \% \mathrm{Pt} / \mathrm{OMCs}^{58}{ }^{58}$ Half of the pores of OMCs $(\sim 5 \mathrm{~nm}$ diameter) are uniformly occupied by Pt nanoparticles $(\sim 2.5 \mathrm{~nm}$ particle size) or are lost during Pt/OMC preparation. In addition to the enhanced metal-accommodation ability, mesoporous carbon also leads to better mass transport according to the polarization plots and electrochemical impedance spectroscopy (EIS) results. ${ }^{59} \mathrm{He}$ et al. have investigated the cyclic voltammograms (CVs) of methanol oxidation on commercial Pt/C (E-TEK) and $\mathrm{Pt} /$ mesoporous carbon nanoparticles (Pt/MCNPs). ${ }^{57}$ In the forward scan, the maximum current density of Pt/MCNPs is 2.3 times higher than that of the E-TEK Pt/C catalyst. Lee et al. used SBA-15 as the template to prepare OMCs supported Pt-Ru for methanol oxidation, achieving a specific surface area about 900 $\mathrm{m}^{2} \mathrm{~g}^{-1}$ and pore size about $4 \mathrm{~nm} .{ }^{60}$ The specific surface area of OMCs is much larger than that of commercial carbon supports (about $240 \mathrm{~m}^{2} \mathrm{~g}^{-1}$, Vulcan XC-72R). ${ }^{61}$ TEM images show that the Pt-Ru nanoparticles are uniformly deposited on OMCs and the particle sizes are limited to $4 \mathrm{~nm}$. They further prepared 
O-doped OMCs by $\mathrm{H}_{2} \mathrm{O}_{2}$ treatment to improve the activity. Ndoped mesoporous carbons are also developed by using nitrogen-containing carbon precursors such as polyacrylonitrile, polypyrrole and polyaniline. ${ }^{62-65}$ Zhang et al. developed a honeycomb-like mesoporous N-doped carbon supported Pt catalyst for methanol oxidation. ${ }^{66}$ Cyclic voltammogram measurements indicate that the peak current density of the $\mathrm{N}$-doped carbon catalyst is 1.4 times higher than that of the carbon catalyst without $\mathrm{N}$ doping. The addition of nitrogen element not only has an intense anchoring effect on Pt nanoparticles, but also enhances the electrical conductivity. The doping of $\mathrm{P}$ heteroatom inhibits the aggregation of metal particles and leads to a uniform distribution on mesoporous carbons, clearly presented in the TEM pictures in Fig. 2E, in contrast with Fig. 2F. ${ }^{67}$ The Pt supported on phosphorus doped OMCs (Pt/ $\mathrm{P}_{7} \mathrm{OMCs}$ ) demonstrates a much higher current density than Pt/OMCs, Pt/Vulcan XC-72 and PtRu/XC in chronoamperometry (see Fig. 2B). Pt/ $\mathrm{P}_{7} \mathrm{OMCs}$ have a relatively stable electrochemical activity and better CO-tolerance towards methanol oxidation. One reason may be the increase of oxygencontaining functional groups after $\mathrm{P}$ doping, which promote CO-tolerance and enhance the stability. It can be found from Fig. 2C that ECSA $\left(90.7 \pm 6.1 \mathrm{~m}^{2} \mathrm{~g}^{-1}\right)$ after a $10000 \mathrm{~s}$ stability test is only a little bit lower than the original value (96.3 \pm $7.3 \mathrm{~m}^{2} \mathrm{~g}^{-1}$ ), and from Fig. 2D that Pt nanoparticles are not obviously aggregated after 10000 s. Moreover, mesoporous carbons incorporated with other compounds, such as ceria, carbon nanotubes, tungsten carbide and tin oxide are also prepared. ${ }^{68-71}$ Ceramic materials such as ceria and tungsten carbide were observed to have a stabilization effect on Pt during the long time test. ${ }^{\mathbf{6 8}, 69}$ Stability tests indicate that the electrochemically active surface of $\mathrm{Pt} / \mathrm{mesoporous}$ carbon-ceria
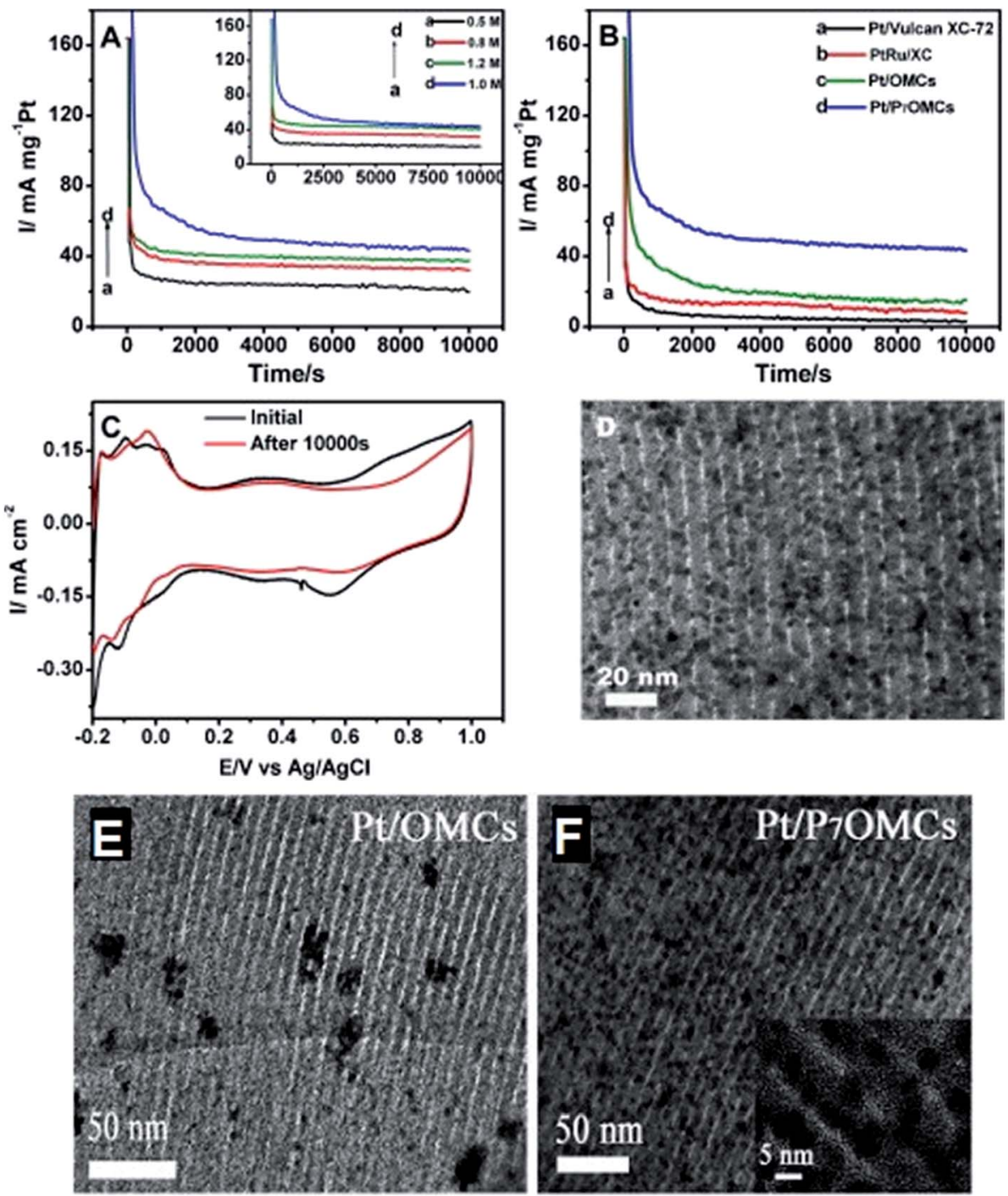

Fig. 2 (A) Chronoamperometry curves of Pt/P7 OMCs at different oxidation voltages: (a) 0.5, (b) 0.6, (c) 0.8, (d) $0.7 \mathrm{~V}$ (inset: with different concentrations of methanol at $0.7 \mathrm{~V}$ ) in a solution of $0.5 \mathrm{M} \mathrm{H}_{2} \mathrm{SO}_{4}+1.0 \mathrm{M} \mathrm{CH} \mathrm{OH}_{3} \mathrm{O}$. (B) Chronoamperometry curves of Pt/Vulcan XC-72, PtRu/XC, $\mathrm{Pt} / \mathrm{OMCs}$ and $\mathrm{Pt} / \mathrm{P}_{7} \mathrm{OMCs}$ recorded at $0.7 \mathrm{~V}$. Scan rate: $50 \mathrm{mV} \mathrm{s}^{-1}$. (C) CVs of Pt/P7OMCs in $0.5 \mathrm{M} \mathrm{H}_{2} \mathrm{SO}_{4}$ before and after $10000 \mathrm{~s}$ stability test. TEM image of (D) Pt/P7 OMCs after 10000 s stability test; (E) Pt/OMCs and (F) Pt/P7OMCs. Reproduced with permission from ref. 67. Copyright 2014, Elsevier. 
reduces by $45 \%$ after accelerated degradation of $2000 \mathrm{~min}$, in comparison to $70 \%$ of conventional $\mathrm{Pt} / \mathrm{C} .{ }^{69}$ Tin oxide is also regarded to enhance the ethanol oxidation on $\mathrm{Pt}$ by effectively splitting the $\mathrm{C}-\mathrm{C}$ bonds in ethanol. ${ }^{71} \mathrm{Pt}$ on carbon nanotubes doped OMCs (Pt/CNTs-OMC) prepared by Zhang et al. exhibit about twice higher current density in methanol oxidation than Pt/CNTs and Pt/OMC (see Fig. 3). ${ }^{70}$ This is because the doping of CNTs forms a unique structure of CNTs-OMC nanocomposites, which is conductive to electron transfer across the OMC particles and results in lowering of the interfacial resistance, illustrated in Fig. 3e. Accordingly, the conductivity of OMC is only $4.3 \mathrm{~S} \mathrm{~m}^{-1}$, and it rises to $26.4 \mathrm{~S} \mathrm{~m}^{-1}$ after doping CNTs. The ECSAs of Pt/OMCs, Pt/CNTs and Pt/CNTs-OMCs are 57.8, 80.4 and $113.4 \mathrm{~m}^{2} \mathrm{~g}^{-1}$, respectively. In brief, all these doped mesoporous carbons present further improvement of activity and durability of Pt-based catalysts for oxidation reaction in comparison with non-doped mesoporous carbon which are big advantages for fuel cell applications.
Besides carbon-based mesoporous supporting materials, non-carbon mesoporous supporting materials (e.g. CrN, TiN, $\mathrm{SnO}_{2}-\mathrm{Sb}$ ) have also been developed for Pt. These supports have a large surface area due to the porous structure. Gurrola et al. claim that after 100 cycles of CVs in acid medium, ECSA of Pt/ $\mathrm{Sb}-\mathrm{SnO}_{2}$ decreases less than $10 \% .{ }^{72}$ In contrast, ECSA of Pt/C decreases significantly attributing to the oxidation of carbon supports. In addition, metal nitride is a better choice for noncarbon supporting materials, as it not only exhibits long-time stability and faster oxidation of CO, but also has high electrical conductivity. Mesoporous TiN is prepared by Yang et al. via a solid-solid phase separation method. ${ }^{73}$ This material is formed by heating $\mathrm{Zn}_{2} \mathrm{TiO}_{4}$ in ammonia gas without a template. Mesoporous TiN demonstrates a high conductivity of $395 \mathrm{~S}$ $\mathrm{cm}^{-1}$ at 35 bar and good electrochemical stability. Accounting to the $\mathrm{CV}$ tests of methanol oxidation, the peak current density of $\mathrm{Pt} / \mathrm{TiN}$ is 1.5 times higher than that of $\mathrm{Pt} / \mathrm{C}$. Yang et al. also prepared mesoporous $\mathrm{CrN}$ with a high conductivity of $54 \mathrm{~S} \mathrm{~cm}^{-1}$
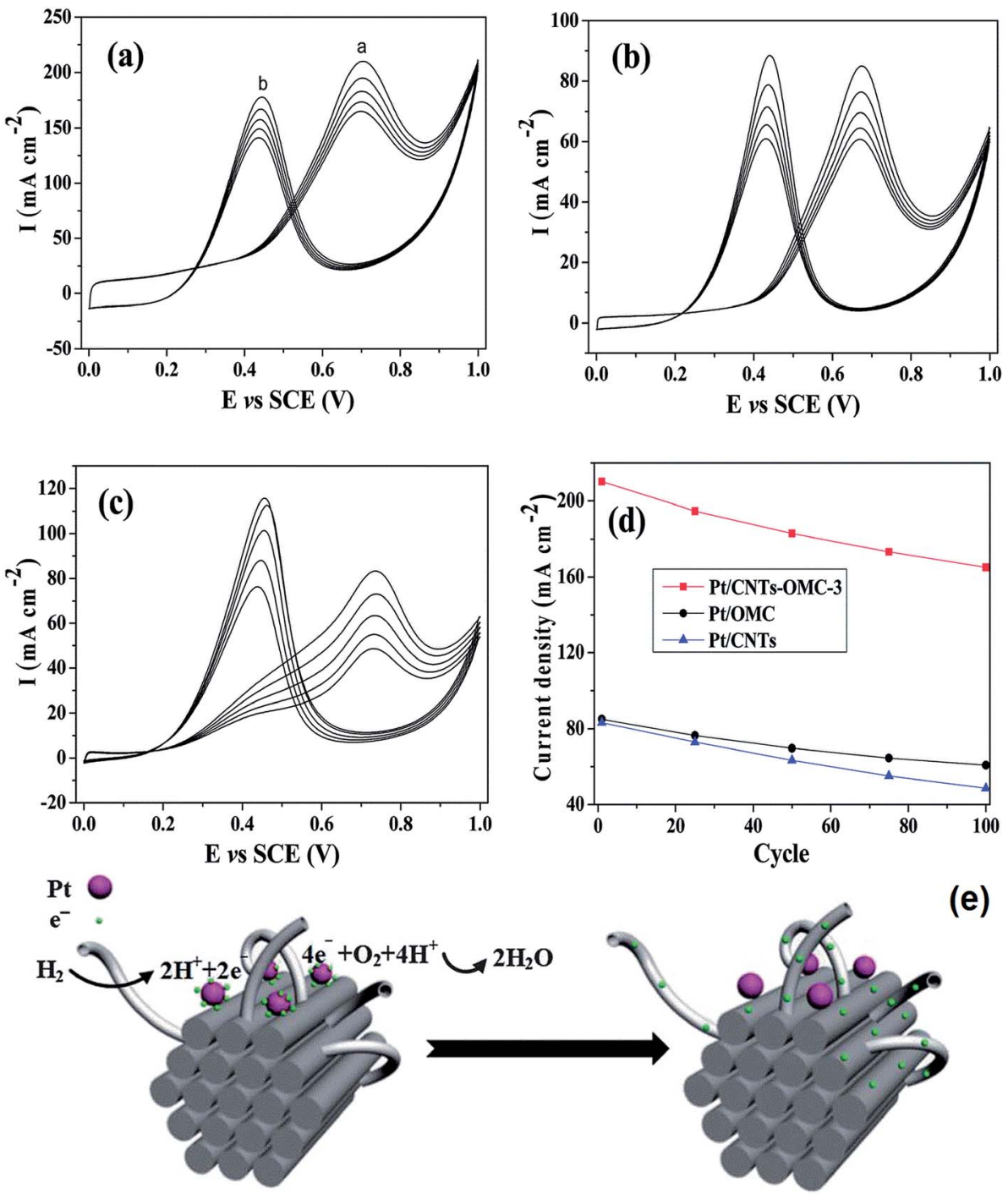

(e)

Fig. 3 Long-term stability of (a) Pt/CNTs-OMC, (b) Pt/OMC and (c) Pt/CNTs in $1.0 \mathrm{~mol} \mathrm{~L}^{-1} \mathrm{H}_{2} \mathrm{SO}_{4}+2.0 \mathrm{~mol} \mathrm{~L}^{-1} \mathrm{CH}_{3} \mathrm{OH}$ with a scan rate of 50 $\mathrm{mV} \mathrm{s}^{-1}$ for 100 cycles and (d) the current density tendency of Pt/CNTs-OMC, Pt/OMC and Pt/CNTs in the forward scan with increasing cycle number. (e) Schematic of electron transport in Pt/CNTs-OMC. Reproduced from ref. 70 with permission from the Royal Society of Chemistry. 
Table 1 A summary of properties of various mesoporous supports

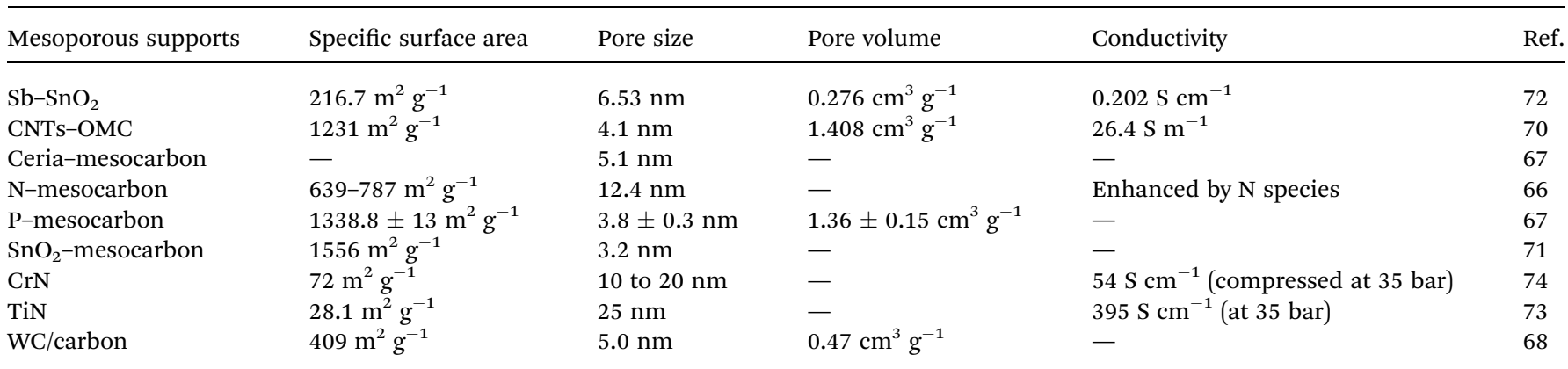

by ammonolysis of $\mathrm{K}_{2} \mathrm{Cr}_{2} \mathrm{O}_{7} \cdot{ }^{74}$ The pore size ranges from 10 to $20 \mathrm{~nm}$, and some microporosity is observed. CrN is electrochemically stable at acidic conditions up to $1.2 \mathrm{~V}$, where carbon materials tend to corrode. When used as a Pt supporting material (Pt/CrN) for methanol oxidation, the synergistic effect of Pt and $\mathrm{CrN}$ allows faster $\mathrm{CO}$ oxidation. The peak current density is $195 \mathrm{~mA} \mathrm{mg}_{\mathrm{Pt}}{ }^{-1}$ for Pt/CrN and $145 \mathrm{~mA} \mathrm{mg}_{\mathrm{Pt}}{ }^{-1}$ for Pt/ C. $\mathrm{Pt} / \mathrm{CrN}$ shows higher electrochemical activity and a slower deterioration rate than $\mathrm{Pt} / \mathrm{C}$. Recently developed mesoporous supports are summarized in Table 1.

The recently reported MMECs and MSMMs for fuel cell anodes achieved enhanced specific mass activity and durability which are superior to those of commercial Pt/C catalysts. MMECs can be prepared in a facile way at room temperature, avoiding the origin of high cost of high-temperature pyrolysis during the MSMM synthesis. In addition, MMECs can also be directly grown on an electrode surface under good contact conditions by the electrodeposition method, ${ }^{34,38,42}$ without the use of costly ionomers to immobilize catalysts onto the electrode surface. The nanostructure, particle size, pore size and elemental composition of MMECs and MSMMs can be designed by choosing the templates and reaction conditions during the synthesis, in order to obtain optimal performance. This provides a promising method for the generation of highperformance and cost-effective metal catalysts for fuel cells with stable performance.

\section{Use of mesoporous materials in cathode catalysts}

The cathode reaction of the oxygen reduction reaction (ORR) is the rate-determining process in PEMFCs, thus there are many investigations into ORR catalysts. The ORR has different reaction routines in acidic and alkaline PEMFCs: ${ }^{75}$

Acidic conditions:

$$
\begin{gathered}
\mathrm{O}_{2}+4 \mathrm{H}^{+}+4 \mathrm{e}^{-} \rightarrow 2 \mathrm{H}_{2} \mathrm{O}\left(4 \mathrm{e}^{-} \text {pathway }\right) \\
\mathrm{O}_{2}+2 \mathrm{H}^{+}+2 \mathrm{e}^{-} \rightarrow \mathrm{H}_{2} \mathrm{O}_{2}\left(2 \mathrm{e}^{-} \text {pathway }\right) \\
\mathrm{H}_{2} \mathrm{O}_{2}+2 \mathrm{H}^{+}+2 \mathrm{e}^{-} \rightarrow 2 \mathrm{H}_{2} \mathrm{O}
\end{gathered}
$$

Alkaline conditions:

$$
\begin{gathered}
\mathrm{O}_{2}+2 \mathrm{H}_{2} \mathrm{O}+4 \mathrm{e}^{-} \rightarrow 4 \mathrm{OH}^{-}\left(4 \mathrm{e}^{-} \text {pathway }\right) \\
\mathrm{O}_{2}+\mathrm{H}_{2} \mathrm{O}+2 \mathrm{e}^{-} \rightarrow \mathrm{HO}_{2}^{-}+\mathrm{OH}^{-}\left(2 \mathrm{e}^{-} \text {pathway }\right) \\
\mathrm{H}_{2} \mathrm{O}+\mathrm{HO}_{2}^{-}+2 \mathrm{e}^{-} \rightarrow 3 \mathrm{OH}^{-}
\end{gathered}
$$

Oxygen can be directly reduced to $\mathrm{H}_{2} \mathrm{O}$ or $\mathrm{OH}^{-}$via a $4 \mathrm{e}^{-}$ pathway, or incompletely reduced to $\mathrm{H}_{2} \mathrm{O}_{2}$ or $\mathrm{HO}_{2}{ }^{-}$via a $2 \mathrm{e}^{-}$ pathway. In proton exchange membrane fuel cells, $\mathrm{H}^{+}$is transported from the anode to cathode to further react with $\mathrm{O}_{2}$, forming $\mathrm{H}_{2} \mathrm{O}$ or $\mathrm{H}_{2} \mathrm{O}_{2}$. The anion exchange membrane based PEMFCs produce $\mathrm{OH}^{-}$as charge carriers via ORR to provide alkaline conditions. This will allow the use of nonprecious transition metals based mesoporous catalysts for fuel cells.

\subsection{Mesoporous cathode electrocatalysts for acidic PEMFCs}

Platinum based metals with carbon supports have good catalytic behaviour toward ORR. Nevertheless, the high cost and activity degradation due to agglomeration of platinum nanoparticles, corrosion of the carbon supports and anode fuel crossover still exist as a bottleneck for wide commercial application. Accordingly, numerous efforts have been made to improve the catalyst performance. Similar to anode catalysts, mesoporous carbon is used as a support for Pt. Liu et al. prepared mesoporous carbon supported Pt, which exhibits higher mass specific kinetic current density than XC-72 carbon supported Pt. ${ }^{76}$ The durability is also improved, as the electrochemical surface area of $\mathrm{Pt} / \mathrm{mesoporous} \mathrm{carbon} \mathrm{decreases} \mathrm{from}$ $24.5 \mathrm{~cm}^{2} \mathrm{mg}_{\mathrm{Pt}}{ }^{-1}$ to $20.6 \mathrm{~cm}^{2} \mathrm{mg}_{\mathrm{Pt}}{ }^{-1}$ and that of $\mathrm{Pt} / \mathrm{XC}-72$ decreases from $21.8 \mathrm{~cm}^{2} \mathrm{mg}_{\mathrm{Pt}}{ }^{-1}$ to $11.1 \mathrm{~cm}^{2} \mathrm{mg}_{\mathrm{Pt}}{ }^{-1}$ under the same conditions. Besides, mesoporous carbon supported Pt can inhibit the formation of $\mathrm{H}_{2} \mathrm{O}_{2}$ with a yield of $0.25 \%$ in ORR, lower than the yield of $1.25 \%$ from Pt/C. ${ }^{77}$

Modified mesoporous carbons and mesoporous metal nitride supported Pt exhibit much more remarkable improvement. You et al. synthesized OMC-SiC composites as a support for Pt by a controlled carbothermal reduction process to utilize both the ordered mesopores of OMC and the high electrochemical stability of the $\mathrm{SiC}$ materials. ${ }^{78}$ The ORR current density using Pt/OMC-SiC shows negligible change $(0.16 \%)$ after 1000 cycles, while the ORR current density using commercial $\mathrm{Pt} / \mathrm{C}$ decreases by $33.4 \%$. The improvement is attributed to a strong interaction of platinum and $\mathrm{Si}$ atom on 
the surface of carbon frameworks, which makes the catalyst more electrochemically stable. In addition, zirconia with the treatment of a sulfonated ionomer has been used to modify mesoporous carbon supports to form zirconia/ionomer/mesoporous carbon. ${ }^{79}$ The mass ORR activity increases from 51 $\mathrm{mA} \mathrm{mg}{ }_{\mathrm{Pt}}{ }^{-1}$ to $74 \mathrm{~mA} \mathrm{mg}{ }_{\mathrm{Pt}}{ }^{-1}$ when the ionomer is used to improve the availability of protons and enhance $\mathrm{O}_{2}$ solubility. Yang et al. tested non-carbon mesoporous CrN supported Pt as a catalyst for ORR. ${ }^{\mathbf{8 0}}$ The specific surface area of $\mathrm{Pt} / \mathrm{CrN}$ is $68.5 \pm 0.1 \mathrm{~m}^{2} \mathrm{~g}^{-1}$. Kinetic current density obtained from polarization curves at $0.9 \mathrm{~V}$ is $9.1 \mathrm{~mA} \mathrm{mg}_{\mathrm{Pt}}{ }^{-1}$ for $\mathrm{Pt} / \mathrm{CrN}$ and $5 \mathrm{~mA} \mathrm{mg}{ }_{\mathrm{Pt}}^{-1}$ for commercial Pt/C, respectively. Another noncarbon mesoporous support for oxygen reduction reaction is TiNbN with a pore size of $30-50 \mathrm{~nm} .{ }^{81}$ Its electrical conductivity reaches $3.9 \mathrm{~S} \mathrm{~cm}^{-1}$, which is about 2.5 times higher than that of Vulcan XC-72 carbon black $\left(1.5 \mathrm{~S} \mathrm{~cm}^{-1}\right)$ under the same measurement conditions. Though its specific surface area is $45 \mathrm{~m}^{2} \mathrm{~g}^{-1}$, which is smaller than that of the mesoporous carbon support, Pt/TiNbN still exhibits larger kinetic current density (256 mA mg $\left.{ }_{\mathrm{Pt}}{ }^{-1}\right)$ than $\mathrm{Pt} / \mathrm{C}\left(142 \mathrm{~mA} \mathrm{mg}_{\mathrm{Pt}}{ }^{-1}\right)$ at $0.9 \mathrm{~V}$. The activity loss of $\mathrm{Pt} / \mathrm{TiNbN}$ and $\mathrm{Pt} / \mathrm{C}$ after 5000 cycles is $19.2 \%$ and $29.4 \%$ respectively, indicating that the stability is improved. In addition, TiNbN is stable both in acidic and alkaline solution.

Transition metal catalysts with mesoporous carbon have been proved to be better than those with carbon black attributing to the increased surface area. ${ }^{\mathbf{8 2 - 8 6}}$ According to Liang's work, a series of mesoporous carbon supported Co (C-N-Co) catalysts are prepared using different templates (silica colloid, ordered mesoporous silica SBA-15, or montmorillonite). ${ }^{85}$ The ORR activity is found to be proportional to the specific surface area, as shown in Fig. 4. As a result, mesoporous carbon supported catalysts (VB12/MMT, VB12/SBA-15, VB12/silica colloid) perform better than carbon black supported catalysts (VB12/C) due to the increase in surface area. Liu et al. prepared stable and methanol-tolerant ORR catalysts, i.e. Fe carbide supported on $\mathrm{N}$-doped carbon, with a high specific area $\left(705 \mathrm{~m}^{2} \mathrm{~g}^{-1}\right)$ and kinetic limiting current density $\left(18.35 \mathrm{~mA} \mathrm{~cm}^{-2}\right.$ at $\left.0.7 \mathrm{~V}\right) .{ }^{87}$

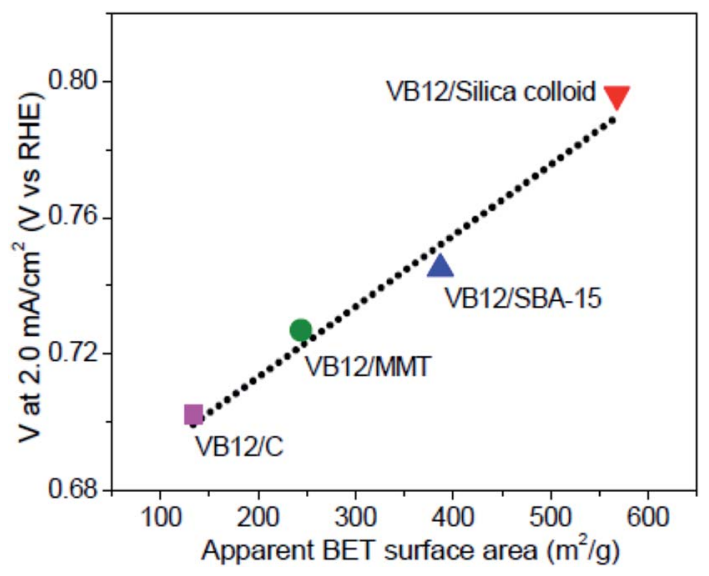

Fig. 4 The correlation between catalyst activity and apparent BET surface areas of the $\mathrm{C}-\mathrm{N}-\mathrm{Co}$ catalysts. Reproduced with permission from ref. 85. Copyright 2013, American Chemical Society.

\subsection{Mesoporous electrocatalysts for alkaline membrane fuel cells}

In alkaline PEMFCs, transition metals such as Fe and Co based compounds supported on mesoporous carbons are also investigated as ORR catalysts in order to avoid the use of noble metals. ${ }^{8-92}$ Cobalt oxide and cobalt sulfide supported on mesoporous carbon or heteroatom doped carbon possess comparable or even higher catalytic activity than commercial $\mathrm{Pt} / \mathrm{C}$ toward ORR. ${ }^{93-96}$ In addition, Co based catalysts are remarkably methanol-tolerant and more stable than Pt/C. For example, in chronoamperometric tests, when the current of $\mathrm{Pt} / \mathrm{C}$ decreased by $26 \%$, the current of $\mathrm{CoS} / \mathrm{N}, \mathrm{S}$-codoped porous carbon reduced by only $8 \%$ under the same conditions. ${ }^{95} \mathrm{~A}$ Ni-doped $\mathrm{Co}_{3} \mathrm{O}_{4}$ nanowire array $\left(n_{\mathrm{Ni}} / n_{\mathrm{Co}}=1: 9\right)$ with a mesoporous structure was used for ORR by Tong et al. recently. ${ }^{97}$ This mesoporous Ni$\mathrm{Co}_{3} \mathrm{O}_{4}$ has a large pore volume of $0.23 \mathrm{~cm}^{3} \mathrm{~g}^{-1}$ with the pore size ranging from 4 to $15 \mathrm{~nm}$, leading to a large surface area of $70.3 \mathrm{~m}^{2} \mathrm{~g}^{-1}$. It exhibits more positive half-wave potential $\left(E_{1 / 2}=\right.$ $0.86 \mathrm{~V})$ and higher diffusion-limiting current density $\left(J_{\mathrm{L}}=\right.$ about $\left.5.76 \mathrm{~mA} \mathrm{~cm}^{-2}\right)$ than $\mathrm{Co}_{3} \mathrm{O}_{4}\left(E_{1 / 2}=0.6 \mathrm{~V}, J_{\mathrm{L}}=1.32 \mathrm{~mA} \mathrm{~cm}^{-2}\right)$ and $\mathrm{Pt} / \mathrm{C}\left(E_{1 / 2}=0.85 \mathrm{~V}, J_{\mathrm{L}}=5.42 \mathrm{~mA} \mathrm{~cm}^{-2}\right)$ catalysts. It is almost insensitive to methanol and $\mathrm{CO}$, and much more stable than $\mathrm{Pt} /$ $\mathrm{C}$ in accelerated ORR measurements. Some studies reported that Fe based mesoporous catalysts possess high catalytic activity comparable with commercial Pt/C, long-time stability and methanol tolerance. ${ }^{\mathbf{9 8 , 9 9}}$ The addition of $\mathrm{Fe}$ has been observed to greatly improve the ORR activity of mesoporous carbon with $\mathrm{N}$ doping due to the high density of surface active sites. $^{\mathbf{9 8 , 9 9}}$ When a trace amount of Fe $(0.2$ at\%) is added, the calculated kinetic current density of $\mathrm{Fe}-\mathrm{N}-\mathrm{C}$ catalyst increases from about $6 \mathrm{~mA} \mathrm{~cm}^{-2}$ (N-C catalyst) to $32.26 \mathrm{~mA} \mathrm{~cm}^{-2}$, which is higher than that of $\mathrm{Pt} / \mathrm{C}\left(30.56 \mathrm{~mA} \mathrm{~cm}{ }^{-2}\right) .{ }^{100}$ It was also noticed that the electron transfer number of ORR changes from 2.61 to 4.04. However, Yang et al. found that the role of Fe was to produce more active $\mathrm{N}$ sites during the catalyst preparation, and the physical presence of $\mathrm{Fe}$ in $\mathrm{N}$-doped carbon was not necessary to enhance the ORR activity. ${ }^{101}$ The activity sites of $\mathrm{Fe}-\mathrm{N}-\mathrm{C}$ need to be further investigated. Until now, great improvement in the use of nonprecious metals based ORR catalysts has been made for both acidic and alkaline PEMFCs, as listed in Table 2, in order to reduce the cost and enhance the performance.

\subsection{Metal-free mesoporous electrocatalysts}

The use of metal based catalysts brings concerns about toxic metal pollution, irreplaceable or rare metal resources and harddegraded substances. The crossover of anode fuels is one of the challenges in fuel cells, and metal based catalysts are active toward both anode and cathode fuels. As a result, fuel cell efficiency will be reduced owing to the undesirable oxidation reaction at the cathode. Carbon materials are renewable and easy to handle, and are tolerant to anode fuels. They are promising materials for cathode catalysts to reach high efficiency and reduce the cost. Furthermore, heteroatoms have different electronegativity and size from carbon atoms, and they can change the charge distribution and electronic properties of pure carbon materials. ${ }^{26,75}$ Tailoring carbon materials by the 
Table 2 Selected ORR catalysts composed of nonprecious transition metals with mesoporous carbon as a supporting material

\begin{tabular}{|c|c|c|c|c|c|}
\hline Catalyst & $\begin{array}{l}\text { Centred pore } \\
\text { diameter }(\mathrm{nm})\end{array}$ & $\begin{array}{l}\text { Specific surface } \\
\text { area }\left(\mathrm{m}^{2} \mathrm{~g}^{-1}\right)\end{array}$ & $\begin{array}{l}\text { ORR onset } \\
\text { potential }\end{array}$ & Performance & Ref. \\
\hline Fe-N/OMC (hollow-core) & 3.5 & 1187 & $0.89 \mathrm{~V} v s . \mathrm{RHE}$ & $\begin{array}{l}\text { ORR current densities at } 0.8 \mathrm{~V} v s . \text { RHE } \\
\text { are }-0.04 \mathrm{~mA} \mathrm{~cm}^{-2} \text { for } \mathrm{Fe}-\mathrm{N} / \text { commercial } \\
\text { carbon (Ketjen black CJ600), and }-1.0 \\
\mathrm{~mA} \mathrm{~cm}{ }^{-2} \text { for } \mathrm{Fe}-\mathrm{N} / \mathrm{OMC}\end{array}$ & 82 \\
\hline $\mathrm{Fe}-\mathrm{N} / \mathrm{OMC}$ & $\sim 22$ & 1138 to 1338 & $\sim 0.8 \mathrm{~V} v s . \mathrm{RHE}$ & $\begin{array}{l}\text { ORR current densities at } 0.55 \mathrm{~V} v s \text {. RHE } \\
\text { are }-1.1 \mathrm{~mA} \mathrm{~cm}^{-2} \text { for } \mathrm{Fe}-\mathrm{N} / \mathrm{commercial} \\
\text { carbon (Black Pearl } 2000 \text { ), and }-1.5 \text { to } \\
-3.0 \mathrm{~mA} \mathrm{~cm}{ }^{-2} \text { for Fe-N/OMC (depending } \\
\text { on the pore diameter) }\end{array}$ & 83,84 \\
\hline Co-N-carbon & 12 & 572 & $\sim 0.87$ vs. RHE & $\begin{array}{l}4.5 \mathrm{~mA} \mathrm{~cm}{ }^{-2} \text { at } 0.3 \mathrm{~V} \text {, better than carbon } \\
\text { black supported } \mathrm{Co}-\mathrm{N}\end{array}$ & 85 \\
\hline CoFe-N-OMC (Co : Fe = $1: 3)$ & 2.4 & 670 & $\sim 0.7 \mathrm{~V} v s$. RHE & $\begin{array}{l}\text { When used as cathode catalysts in fuel } \\
\text { cell tests, at a cell voltage of } 0.3 \mathrm{~V} \text {, current } \\
\text { density of PAIN/CoFe/OMC and } \\
\text { commercial Pt/C is } 0.89 \text { and } 1.07 \mathrm{~A} \mathrm{~cm}^{-2} \text {, } \\
\text { respectively }\end{array}$ & 86 \\
\hline $\mathrm{CoO} / \mathrm{N}-$ carbon & 3.3 & 1390 & $-0.06 \mathrm{~V} v s . \mathrm{Ag} / \mathrm{AgCl}$ & $\begin{array}{l}\text { Kinetic-limited current density reaches } \\
22.29 \mathrm{~mA} \mathrm{~cm}{ }^{-2} \text { at }-0.4 \mathrm{~V} \text {, higher than } \\
\text { that of commercial } \mathrm{Pt} / \mathrm{C}\left(21.32 \mathrm{~mA} \mathrm{~cm}^{-2}\right) \text {; } \\
\text { largely improved methanol tolerance }\end{array}$ & 94 \\
\hline $\mathrm{CoS} / \mathrm{N}, \mathrm{S}-$ carbon & $\mathrm{N} / \mathrm{A}$ & 248 & $0.92 \mathrm{~V} v s . \mathrm{RHE}$ & $\begin{array}{l}\text { ORR current density reaches }-4.50 \mathrm{~mA} \\
\mathrm{~cm}^{-2} \text { at } 0.45 \mathrm{~V} \text { vs. RHE, largely improved } \\
\text { methanol tolerance }\end{array}$ & 95 \\
\hline $\mathrm{CoS}_{2}$ /graphene oxide & 2.5 to 3.5 & 10 to 19 & $0.97 \mathrm{~V} v s . \mathrm{RHE}$ & $\begin{array}{l}\text { ORR potential at }-3 \mathrm{~mA} \mathrm{~cm}{ }^{-2} \text { is } 0.76 \mathrm{~V} \\
\text { for } \mathrm{CoS}_{2} / \text { graphene oxide and } 0.86 \mathrm{~V} \text { for } \\
\mathrm{Pt} / \mathrm{C}\end{array}$ & 96 \\
\hline $\mathrm{Fe}-\mathrm{N}$-carbon & 3.0 to 5.5 & 236 & $0.95 v s$. RHE & $\begin{array}{l}\text { Kinetic current density is } 7.40 \mathrm{~mA} \mathrm{~cm}{ }^{-2} \\
\text { at } 0.82 \mathrm{~V} \text {, higher than that for Pt/C }(6.30 \\
\mathrm{mA} \mathrm{cm}\end{array}$ & 99 \\
\hline $\mathrm{Fe} /$ carbon-N, $\mathrm{Co} /$ carbon-N & 3.4 to 4.9 & 700 to 860 & $\sim 0.8 \mathrm{~V} v s . \mathrm{RHE}$ & $\begin{array}{l}\text { Single cell PEMFC current density at } 0.6 \mathrm{~V} \\
\text { vs. RHE: }-0.1 \mathrm{~A} \mathrm{~cm}^{-2} \text { for } \mathrm{Fe} / \mathrm{OMC}-\mathrm{N} \text {; } \\
-0.06 \mathrm{~A} \mathrm{~cm}^{-2} \text { for } \mathrm{Co} / \mathrm{OMC}-\mathrm{N} ;-0.3 \mathrm{~A} \\
\mathrm{~cm}^{-2} \text { for commercial } \mathrm{Pt} / \mathrm{C}\end{array}$ & 102 \\
\hline
\end{tabular}

introduction of heteroatoms to obtain metal-free catalysts with ideal ORR activity is a hot issue nowadays. In recent years, nitrogen-doped carbon with N-containing polymers, ammonia, as well as nitrogen gas as the nitrogen source or the source of both nitrogen and carbon has been developed, which possesses good ORR activity. ${ }^{103-108}$ Further developments on the combination of mesoporous carbon materials with heteroatom doping make metal-free catalysts a potential substitution for the $\mathrm{Pt} / \mathrm{C}$ catalyst.

In a recent study, the SBA-15 template was impregnated with pyrrole as both the carbon and nitrogen source via vaporization-capillary condensation in a vacuum container, and then formation of the nitrogen-doped OMC after polymerization and etching. ${ }^{109}$ The ORR current density at $0.9 \mathrm{~V}$ reached $0.07,0.09$ and $0.12 \mathrm{~mA} \mathrm{~cm}{ }^{-2}$ when the pyrolysis temperature was at $800{ }^{\circ} \mathrm{C}, 900{ }^{\circ} \mathrm{C}$ and $1000{ }^{\circ} \mathrm{C}$ respectively. Furthermore it was found that nitrogen-activated carbon $(\mathrm{C}-\mathrm{N})$ is the active site for the ORR because current density increases with the $\mathrm{C}-\mathrm{N}$ fraction. Zhang et al. developed a simple template-free method to fabricate nitrogen-doped porous carbon foam from melamineformaldehyde foam by a two-step pyrolysis process: heating at $300{ }^{\circ} \mathrm{C}$ in air and then at $1000{ }^{\circ} \mathrm{C}$ in a $\mathrm{N}_{2}$ atmosphere. ${ }^{110}$ This carbon foam ( 4.3 at $\% \mathrm{~N}$ content) has a small pore size below $5 \mathrm{~nm}$ and gives rise to a high specific surface area of $980 \mathrm{~m}^{2} \mathrm{~g}^{-1}$. 
Rotating disk electrode (RDE) voltammograms are used to investigate the ORR pathway of this carbon foam. It reveals that the average electron transfer number is about 3.6 with little hydrogen peroxide generation. The ORR activity of carbon foam is slightly lower than that of $\mathrm{Pt} / \mathrm{C}$, but the methanol-tolerance is largely improved. Nanoporous carbon nanocables with carbon nanotubes as the core and $\mathrm{N}$-doped carbon as the shell have been prepared by Jiang et al. ${ }^{111}$ This core-shell catalyst has a specific surface area of $413 \mathrm{~m}^{2} \mathrm{~g}^{-1}$ and pore diameter range from 1.7 to $4 \mathrm{~nm}$. It demonstrates much higher ORR activity than the catalyst with a core or shell only. It achieves a fourelectron transfer in ORR with high catalytic activity comparable with $\mathrm{Pt} / \mathrm{C}$ and remarkable methanol tolerance. Nitrogen-doped hollow mesoporous carbon spheres (HMCSs) were also prepared based on mesoporous silica spheres (MSSs) as shown in Fig. 5. ${ }^{112}$ MSSs are initially formed from tetraethylorthosilicate (TEOS) and trimethoxy(octadecyl) silane $\left(\mathrm{C}_{18} \mathrm{TMS}\right)$, then HMCSs are prepared after carbonization with the addition of nitrogen and carbon sources and HF washing. The nitrogen sources for HMCS-1 and HMCS-2 are glycine and lysine, respectively, and glucose for HMCS-3 (no nitrogen doping). After forming a hollow structure, the specific surface area increases from $335 \mathrm{~m}^{2} \mathrm{~g}^{-1}$ (MSSs) to $451 \mathrm{~m}^{2} \mathrm{~g}^{-1}$ (HMCSs). Among the three prepared metal free catalysts toward ORR, HMCS-1 is the most active one, which displays comparable although inferior ORR activity to the commercial Pt/C catalyst (see Fig. 5E and F). HMCSs show excellent methanol tolerance as they are inactive toward methanol, so they are a promising catalyst to replace Pt catalysts and achieve high efficiency. Moreover, another route has been reported to prepare hollow nitrogen-doped carbon (HNC) as a simple, environmental friendly, economic and template-free synthesis method, as shown in Fig. $6 .{ }^{113}$ Aniline monomer was polymerized with the addition of $\mathrm{K}_{3}\left[\mathrm{Fe}(\mathrm{CN})_{6}\right]$ in an ice bath $\left(<5^{\circ} \mathrm{C}\right)$ for $24 \mathrm{~h}$, followed by washing and carbonization to form a hollow and porous structure. Trace Fe $(0.13$ at\%) was left in HNC, with C, O, N contents of $86.55,11.87$, and 1.95 at\%. Fig. $6 \mathrm{a}$ and b demonstrate that $\mathrm{HNC}$ is close to commercial Pt/C in ORR activity. In addition, the HNC has advantages of better methanol crossover resistance and long-term durability in alkaline medium. This feature is excellent for methanol fuelled alkaline membrane fuel cells.

Dual elements doped mesoporous carbon was also prepared as an ORR catalyst, such as B-, N-doped carbon nanofibers, S-, $\mathrm{N}$-doped mesoporous carbon, and $\mathrm{O}-, \mathrm{N}$-doped mesoporous carbon. Mesoporous carbon doped with $\mathrm{N}$ and $\mathrm{O}$ was fabricated by the thermal treatment of PANI/SBA-15 and silica etching. ${ }^{64}$ The heating temperature $\left(600{ }^{\circ} \mathrm{C}\right.$ to $\left.900{ }^{\circ} \mathrm{C}\right)$ could affect the $\mathrm{N}$ and $\mathrm{O}$ contents in mesoporous carbon. Nitrogen atoms were observed to decrease with increase in temperature. In contrast, $\mathrm{O}$ atoms would increase as the $\mathrm{O}$ is introduced from the mesoporous silica driven by the high temperature. The current density of ORR achieved from mesoporous $\mathrm{N}$-, O-carbon synthesized at a pyrolysis temperature of $800{ }^{\circ} \mathrm{C}$ is larger than that of Pt/C. Qi Shi et al. prepared two kinds of B, N-codoped mesoporous carbon nanofibers, namely $\mathrm{BNC}_{\mathrm{f}}-\mathrm{N}$ and $\mathrm{BNC}_{\mathrm{f}}$ NA. ${ }^{114} \mathrm{BNC}_{\mathrm{f}} \mathrm{N}$ is pyrolysed with a mixture of boric acid/urea under $\mathrm{N}_{2}$, and $\mathrm{BNC}_{\mathrm{f}}-\mathrm{NA}$ is further treated under $\mathrm{NH}_{3}$. The $\mathrm{B}-\mathrm{N}-$ $\mathrm{C}$ sites can enhance the ORR activity and demonstrate the synergistic effect of B, N-codoping. Raman and XPS spectra
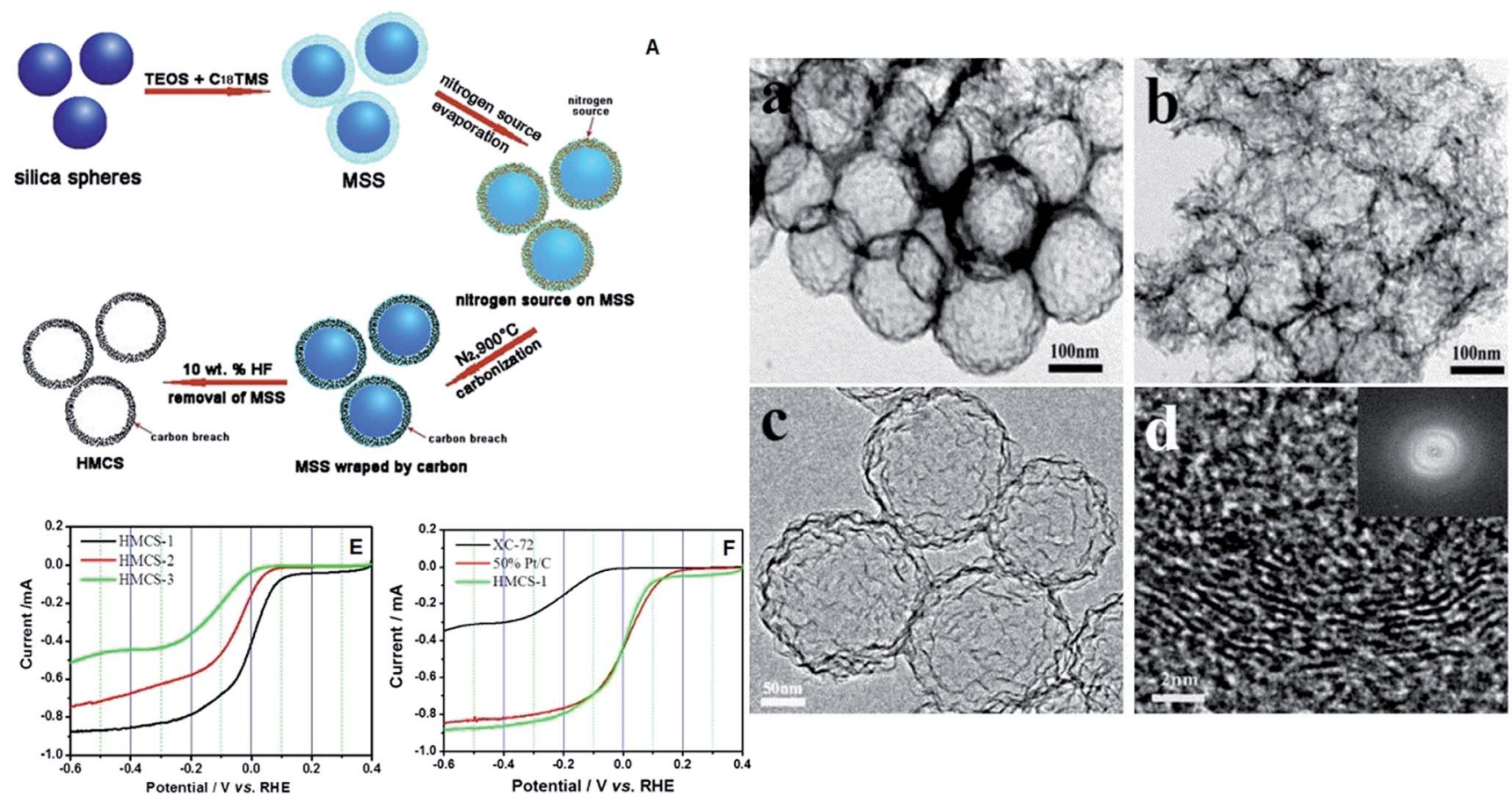

Fig. 5 (A) Schematic illustration of the formation of HMCSs; TEM micrographs of HMCS-1 (a) and HMCS-2 (b); HRTEM micrographs (c and d) and SAED (inset in d) of HMCS-1; ORR polarization curves of HMCSs (E) and Pt/C (F) in $\mathrm{O}_{2}$ saturated $0.1 \mathrm{M} \mathrm{KOH}$ solution, sweep rate: $10 \mathrm{mV} \mathrm{s}{ }^{-1}$, rotation speed: 1600 rpm. Reproduced with permission from ref. 112. Copyright 2014, Elsevier. 

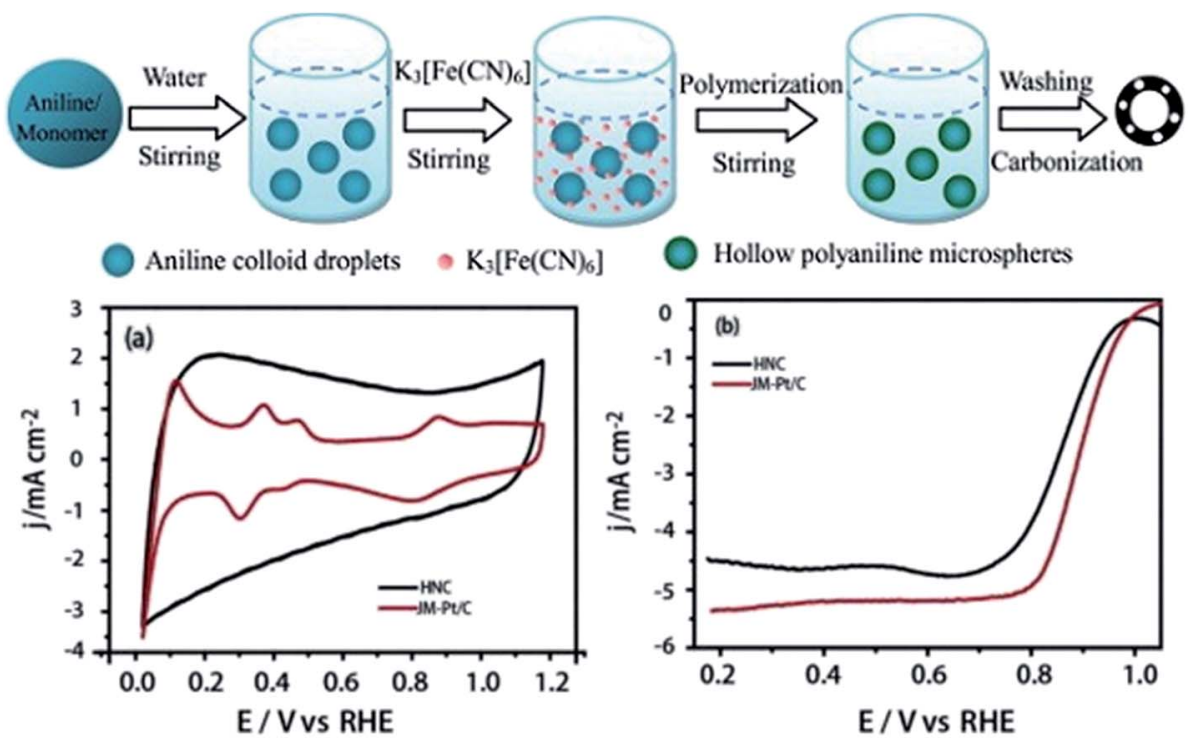

Fig. 6 Schematic representation of the synthesis of hollow nitrogen-doped carbon; (a) CV curves of HNC and commercial Pt/C catalysts in $0.1 \mathrm{M}$ $\mathrm{KOH}$ at a sweep rate of $50 \mathrm{mV} \mathrm{s}^{-1}$. (b) LSV curves of $\mathrm{HNC}$ and commercial Pt/C catalysts in $\mathrm{O}_{2}$ saturated $0.1 \mathrm{M} \mathrm{KOH}$ at a sweep rate of $10 \mathrm{mV} \mathrm{s}$ and $1600 \mathrm{rpm}$ rotating speed. Reproduced with permission from ref. 113. Copyright 2015, Elsevier.

show that the content of defect sites is enhanced after $\mathrm{NH}_{3}$ activation. The relative amount of pyridinic-N, which is favourable for ORR, increased from $13\left(\mathrm{BNC}_{\mathrm{f}} \mathrm{N}\right)$ to 41 at $\%$ $\left(\mathrm{BNC}_{\mathrm{f}} \mathrm{NA}\right)$ after $\mathrm{NH}_{3}$ activation, as shown in Fig. 7. The specific surface area increased from $24.7\left(\mathrm{BNC}_{\mathrm{f}} \mathrm{N}\right)$ to $306.3 \mathrm{~m}^{2} \mathrm{~g}^{-1}$ $\left(\mathrm{BNC}_{\mathrm{f}} \mathrm{NA}\right)$ after $\mathrm{NH}_{3}$ activation. Compared with commercial Pt/ $\mathrm{C}$ catalysts, the metal free $\mathrm{BNC}_{\mathrm{f}} \mathrm{-NA}$ catalyst shows high electrocatalytic efficiency, much better stability and methanol tolerance thus a promising alternative to the $\mathrm{Pt} / \mathrm{C}$ ORR catalyst.
To date, S-, N-doped porous carbon materials have been reported with different $\mathrm{N}$ and $\mathrm{S}$ sources, as shown in Table 3. Normally $\mathrm{N}$ and $\mathrm{S}$ co-doped carbon catalysts present a larger electron transfer number compared to sole $\mathrm{N}$ or $\mathrm{S}$ doped carbon catalysts, leading to high efficiency of ORR. ${ }^{115-117}$ Sulphur atoms bonding with carbon have a thiophene-like structure, which has been proved to improve the catalysts with sole nitrogen doping due to the synergistic effects originating from $\mathrm{S}$ and $\mathrm{N}$ atoms. ${ }^{116-118}$ For example, S-, N-doped porous carbon foam
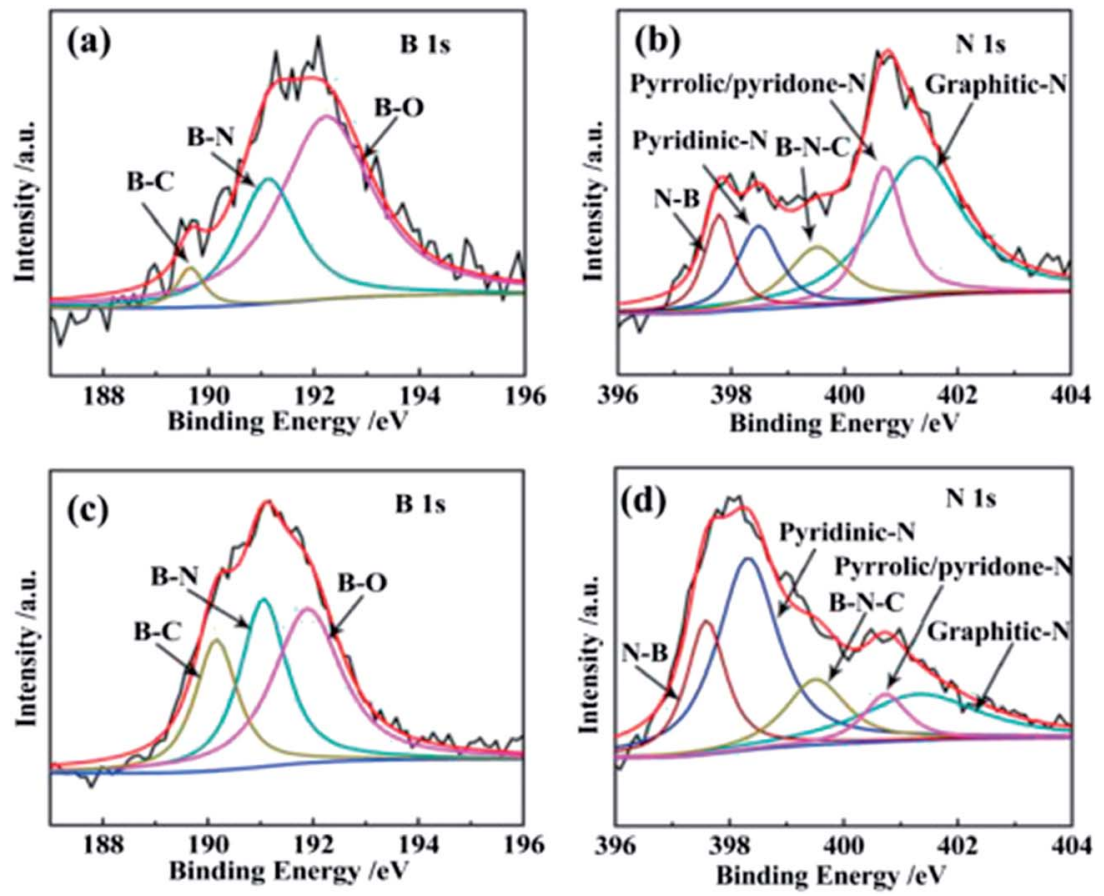

Fig. 7 B 1s and N 1s XPS spectra of (a and b) $\mathrm{BNC}_{f}-\mathrm{N}$ and (c and d) $\mathrm{BNC}_{f}-\mathrm{NA}$. Reproduced with permission from ref. 114. Copyright 2015, Elsevier. 


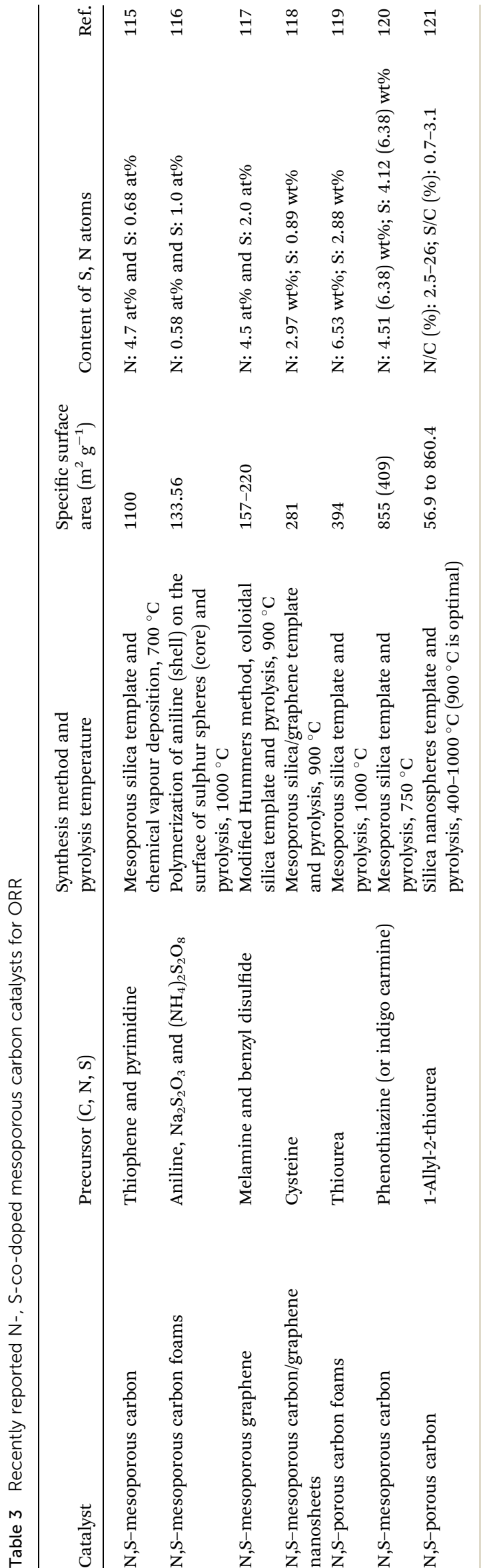

exhibits an ORR onset potential close to that of Pt/C, and its current density is higher with a limited-kinetic current density of $11.69 \mathrm{~mA} \mathrm{~cm}{ }^{-2}$ at $-0.40 \mathrm{~V} .{ }^{119}$ Rotating-disk voltammetry measurements show that the electron transfer number is 3.96 , indicating a high-efficiency four-electron process with negligible formation of $\mathrm{H}_{2} \mathrm{O}_{2}$.

Gao et al. reported N-, S-, and P-tridoped porous carbon fabricated from the pyrolysis of worst weed (Eclipta prostrata). ${ }^{122}$ Heteroatoms were directly introduced from the natural compounds of worst weed. The as-prepared tri-doped carbon consists of mesopores with diameter from 5 to $30 \mathrm{~nm}$ and a small number of macropores with diameter from 100 to 150 $\mathrm{nm}$. The pore volume and specific surface area reach $0.2676 \mathrm{~cm}^{3}$ $\mathrm{g}^{-1}$ and $378.5 \mathrm{~m}^{2} \mathrm{~g}^{-1}$, respectively. This (N, S, P)-doped carbon achieves higher catalytic activity and better durability toward four-electron ORR in comparison with the $\mathrm{Pt} / \mathrm{C}$ catalyst.

Pyrolysis temperature is a vital factor in the synthesis of heteroatoms doped mesoporous carbon, which can largely affect the catalytic activity as well as the number of electrons transferred for ORR. The optimal pyrolysis temperature is around $900{ }^{\circ} \mathrm{C}$ according to the reported studies, and it may vary because of the different carbon and heteroatom precursors used. ${ }^{64,109,111,115-117,119,121}$ If the pyrolysis temperature is too low, the carbon sheath will not be adequately graphitized, thus the as-prepared mesoporous carbon will be of poor electrical conductivity. If the pyrolysis temperature is too high, active sites in the as-prepared mesoporous carbon will decrease due to the low heteroatom doping level (density). Besides, the specific surface area and pore volume of mesoporous carbon are also influenced by the pyrolysis temperature. For these reasons, optimal preparation conditions need to be investigated in order to make heteroatom doped mesoporous carbon a potential substitute for the commercial Pt/C catalyst with enhanced ORR activity, complete reduction product, long stability and methanol tolerance.

\section{Fuel cell performance using electrocatalysts with a mesoporous structure}

Although many studies reported the superior performance of mesoporous catalysts toward anode and cathode reactions characterized by electrochemical measurements in three-electrode systems, it was still required to be further verified by practical fuel cell performance. The three-electrode measurements are performed in bulk electrolytes with catalysts in direct contact with fuels. In fuel cell electrodes, liquid or gas fuels need to pass through the diffusion layer to reach the catalyst layer. As a fuel cell is a more complicated system, many factors such as MEA fabrication (Nafion loading, gas diffusion layer, press process, etc.) and operation conditions (temperature, flow rate, humidity, etc.), barring its catalyst properties, will affect its current density, which probably diminish the superiority of mesoporous catalysts. For example, when $\mathrm{Pt} /$ mesoporous carbon (Pt/MC) is assembled at the cathode in a $\mathrm{H}_{2} / \mathrm{O}_{2}$ fuel cell, the power density is higher than that of the $\mathrm{Pt} / \mathrm{C}$ cathode at 
$60{ }^{\circ} \mathrm{C} .{ }^{123}$ However, the power densities become similar when the operation temperature is $30^{\circ} \mathrm{C}$. Ahn et al. found that Pt particles in Pt/MC could deposit on two or more ordered carbon nanorods to share the Nafion ionomer and electrolyte, thus less ionomer loading was required. The optimal Nafion loading at the cathode for $\mathrm{Pt} / \mathrm{MC}(10 \mathrm{wt} \%)$ is found to be lower than that for $\mathrm{Pt} / \mathrm{C}(20$ and $30 \mathrm{wt} \%){ }^{58}$ In direct methanol fuel cells (DMFCs) at $80{ }^{\circ} \mathrm{C}, \mathrm{Pt} / \mathrm{MC}$ assembled in the anode showed a maximum power density $8 \%$ higher than that of $\mathrm{Pt} / \mathrm{C}$, but $\mathrm{Pt} /$ MC assembled in the cathode even showed slightly lower maximum power density than $\mathrm{Pt} / \mathrm{C}$, and its best Nafion loading was $35 \% .{ }^{77}$ The flow rate of fuels also has different effects on Pt/ MC and Pt/C. Recently Bruno et al. prepared Pt/MC with $5.3 \mathrm{~nm}$ $\mathrm{Pt}$ particle size, which is $25 \%$ smaller than that of $\mathrm{Pt} / \mathrm{C}$ (Vulcan carbon). ${ }^{124}$ When Pt/MC and Pt/C are used as cathode catalysts, the maximum power density of DMFCs reaches $30 \mathrm{~mW} \mathrm{~cm} \mathrm{~cm}^{-2}$ and $16 \mathrm{~mW} \mathrm{~cm}^{-2}$ respectively when air was used at the cathode. They found that although mesoporous catalysts could reduce the mass transport losses promoting the water transportation, they would also promote the drying out of the MEA at high flow rates. As shown in Fig. 8A, the highest power is achieved at 100 sccm air flow, and the power will reduce as the air flow increases to $150 \mathrm{sccm}$ when using $\mathrm{Pt} / \mathrm{MC}$ as the cathode catalyst. In contrast, in Fig. 8B, the power is observed to keep increasing with air flow up to $150 \mathrm{sccm}$ when using Pt/C. Thus it is of vital importance for practical application of mesoporous catalysts to optimize MEA preparation and the operation conditions of polymer electrolyte membrane fuel cells.

In most reported studies, better results have been observed with mesoporous catalysts in fuel cell tests due to their merits as shown in Table 4 . The Pt or Pt-alloy particles $(\sim 3 \mathrm{~nm})$ can only be dispersed on the surface of microporous supports $(<2 \mathrm{~nm}$ in pore size), which aggregate easily and give rise to low ECSA. In addition, the Nafion ionomer fails to enter pores with diameter smaller than $20 \mathrm{~nm}$, showing poor contact between the metal nanoparticles and the Nafion ionomer. ${ }^{125,126}$ In contrast, the adequate pore size of mesoporous supports leads to more Pt dispersion and fuels accessible in mesopores. ${ }^{\mathbf{1 2 6}} \mathrm{Pt}$ particles in the mesopores could share the Nafion ionomer and fuels, thus less ionomer loading was required. ${ }^{58}$ The $\mathrm{H}_{2} \mathrm{O}$ produced by electrochemical reactions can easily transfer from the catalyst layer to the gas diffusion layer with less space occupied by the ionomer. Thus the mesoporous structure is favourable for mass transport in the catalyst layer. ${ }^{\mathbf{1 2 6 , 1 2 7}}$ On the anode side, when assembled with $\mathrm{PtRu} / \mathrm{C}$, the maximum power density of DMFC reaches $17 \mathrm{~W} \mathrm{~g}_{\mathrm{Pt}}{ }^{-1}\left(34 \mathrm{~mW} \mathrm{~cm}^{-2}\right)$ and $26 \mathrm{~W} \mathrm{~g}_{\mathrm{Pt}}{ }^{-1}\left(61 \mathrm{~mW} \mathrm{~cm}^{-2}\right)$
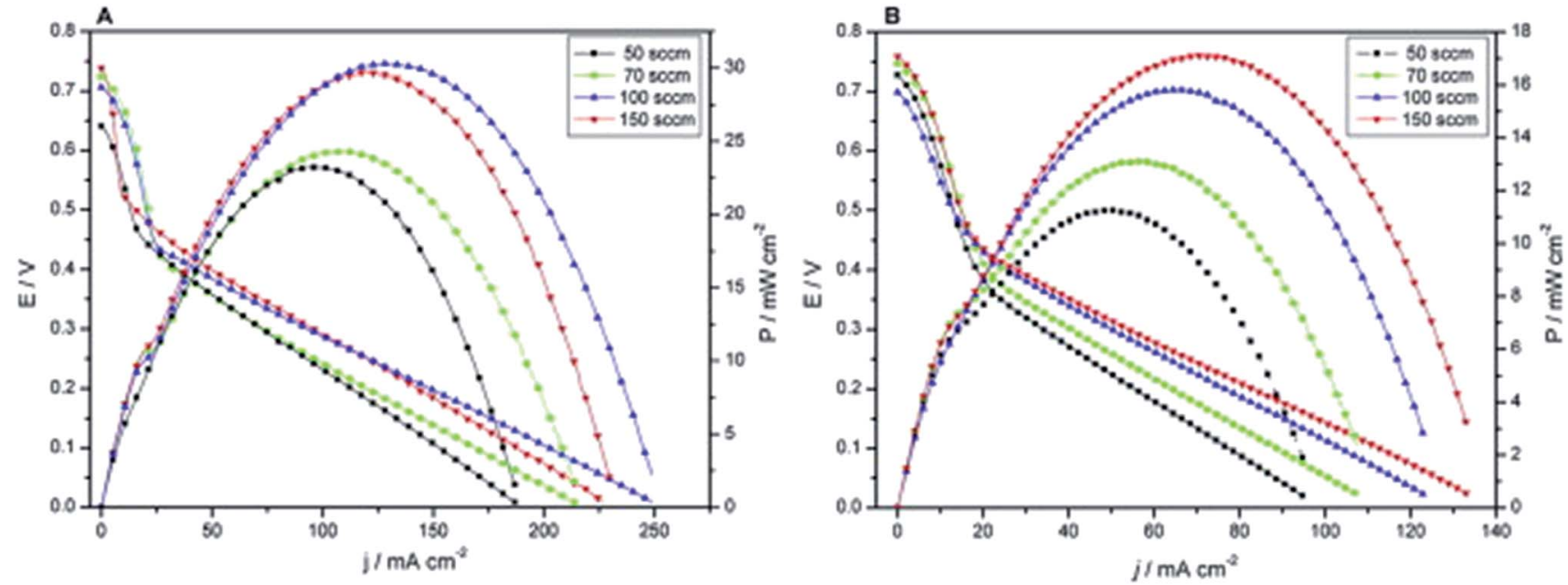

Fig. 8 Polarization and power curves at different air flows for (A) Pt/mesoporous carbon and (B) Pt/Vulcan carbon at $60{ }^{\circ} \mathrm{C}$ and $1 \mathrm{M}$ methanol as an anode fuel. Reproduced with permission from ref. 124. Copyright 2015, Elsevier.

Table 4 Comparisons between mesoporous catalysts and traditional carbon supported Pt (Pt alloys) applied in fuel cell electrodes

\begin{tabular}{ll}
\hline & Mesoporous catalysts \\
\hline $\begin{array}{l}\text { Pt dispersion } \\
\text { Mass transport of fuels }\end{array}$ & $\begin{array}{l}\text { Uniform with high specific area } \\
\text { Good access to fuels due to adequate pore sizes } \\
\text { and volumes }\end{array}$ \\
MEA preparation & $\begin{array}{l}\text { Applicable to alkaline and acidic membranes, } \\
\text { less ionomer loading required } \\
\text { Enhanced thermal, chemical and mechanical } \\
\text { stability, tolerant to methanol crossover } \\
\text { (heteroatom doped carbon) } \\
\text { Cost-effective, noble-metal-free }\end{array}$ \\
Price &
\end{tabular}
Traditional carbon supported Pt (Pt alloys)

Easy to aggregate

Pore size too small to obtain adequate fuels, pore space tends to be filled with $\mathrm{H}_{2} \mathrm{O}$ to slow down mass transport

Applicable to alkaline and acidic membranes, normally $20-40 \mathrm{wt} \%$ of ionomer loading Degeneration of carbon black, not tolerant to methanol crossover

High price due to the use of noble metals 
at $30{ }^{\circ} \mathrm{C}$ and $60{ }^{\circ} \mathrm{C}$ respectively. ${ }^{59}$ It increases to $31 \mathrm{~W} \mathrm{~g}{ }_{\mathrm{Pt}}{ }^{-1}$ $\left(40 \mathrm{~mW} \mathrm{~cm}^{-2}\right)$ at $30{ }^{\circ} \mathrm{C}$ and $45 \mathrm{~W} \mathrm{~g} \mathrm{gt}^{-1}\left(67 \mathrm{~mW} \mathrm{~cm}^{-2}\right)$ at $60{ }^{\circ} \mathrm{C}$ when assembled with $\mathrm{PtRu} / \mathrm{MC}$, attributing to the fast oxidation rate and enhanced mass transport of methanol with mesoporous catalysts. Song et al. reported that ultrafine porous carbon fiber (with pores in the range of 5-30 nm diameter) can be formed in a straightforward manner after the carbon fiber is oxidized at $280{ }^{\circ} \mathrm{C}$ and subsequently carbonized at $1400{ }^{\circ} \mathrm{C} .{ }^{128}$ Carbon fiber is prepared via electro-spinning of polyacrylonitrile/polymethyl methacrylate (PAN/PMMA) blend solution on aluminium foil. Platinum supported on this carbon fiber makes the power density 1.25 times higher than that of commercial Pt/C in single fuel cell tests at room temperature. On the cathode side, mesoporous carbon doped with heteroatoms or Fe and Co has shown better performance in fuel cells than Pt/ C. ${ }^{\mathbf{8 6 , 1 0 0 , 1 0 9}}$ Mesoporous carbon doped with $\mathrm{Fe}$ and $\mathrm{N}$ achieves

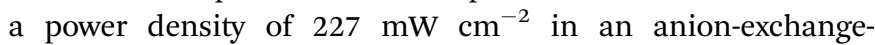
membrane based alkaline methanol fuel cell, which is higher than the $195 \mathrm{~mW} \mathrm{~cm}{ }^{-2}$ achieved from Pt/C. ${ }^{100}$ Wan et al. reported that the $\mathrm{N}$-doped mesoporous carbon exhibited twice higher power density of DMFC than Pt/C. ${ }^{109}$ The reason was not only that $\mathrm{N}$-doped mesoporous carbon showed higher ORR activity, but also that it was inactive toward methanol thus eliminating the negative effect of methanol crossover.

\section{Summary and outlook}

This mini-review summarises recent developments and exciting research in the application of mesoporous materials as anode and cathode electrocatalysts in polymer membrane fuel cells. For anode catalysts, mesoporous Pt based metals have been prepared via template-assisted reduction or sputtering deposition methods. They have shown increased specific surface area, improved electrochemical activity and tolerance to poisoning due to the optimal mesoporous structure. More studies have been done to obtain high-performance catalysts with metals supported on mesoporous materials. The developments of mesoporous carbon and other inorganic compounds have solved the problem of poor electrical conductivity in silica-based mesoporous materials and broadened their applications in electrocatalysts. For cathode catalysts, Pt-based mesoporous catalysts have achieved enhanced specific mass activity and stability in comparison with commercial $\mathrm{Pt} / \mathrm{C}$, but they are not tolerant to methanol crossover. In contrast, heteroatom doped mesoporous carbon is inactive toward anode fuels (methanol), so it has improved durability and high fuel cell efficiency, though its ORR activities are slightly lower than those of Pt-based mesoporous catalysts. Additionally, various kinds of organic compounds and even natural biomass can be used as sources to prepare heteroatom doped mesoporous carbon, leading to a great reduction of catalyst cost. The mesoporous supporting materials have some advantages over commercial carbon supports, including (1) several times larger specific surface area and high accessible surface area to support metal deposition, (2) good catalyst-support interaction, (3) high electrical conductivity, (4) good mass transfer of fuels in pores, (5) uniform and small metallic nanoparticle dispersion and (6) strong corrosion resistance. As a result, mesoporous electrocatalysts have shown better performance than commercial Pt/C. However, mesoporous anode catalysts without noble metals and mesoporous catalysts for nitrogen-containing fuel oxidation have not been intensively studied. It was found that Pt-based catalysts are easily poisoned by the adsorbed $\mathrm{N}_{\mathrm{ads}}$, and thus limits the current density and service life. ${ }^{\mathbf{1 2 9 - 1 3 1}}$ As mesoporous catalysts have demonstrated both activity and CO-tolerance improvement, they may also be considered as noble metal free and $\mathrm{N}_{\text {ads }}$-tolerant catalyst anode materials for fuel cells in the future.

\section{Acknowledgements}

The authors thank the EPSRC Supergen fuel cell project (EP/ G030995/1) for funding. One of the authors (Xu) gratefully acknowledges the China Scholarship Council (CSC) for financial support.

\section{References}

1 N. V. Rees and R. G. Compton, Energy Environ. Sci., 2011, 4, 1255-1260.

2 L. An, T. S. Zhao and Y. S. Li, Renewable Sustainable Energy Rev., 2015, 50, 1462-1468.

3 R. Lan, S. W. Tao and J. T. S. Irvine, Energy Environ. Sci., 2010, 3, 438-441.

4 E. Antolini, J. R. C. Salgado and E. R. Gonzalez, Appl. Catal., $B, 2006,63,137-149$.

5 J. Jiang and A. Kucernak, J. Electroanal. Chem., 2009, 630, 10-18.

6 A. Serov and C. Kwak, Appl. Catal., B, 2010, 98, 1-9.

7 X. Luo, J. Wang, M. Dooner and J. Clarke, Appl. Energy, 2015, 137, 511-536.

8 R. Lan and S. W. Tao, J. Power Sources, 2011, 196, 50215026.

9 H. Zhang, W. Xu, D. Feng, Z. Liu and Z. Wu, Bioresour. Technol., 2016, 203, 56-61.

10 T. Hua, R. Ahluwalia, L. Eudy, G. Singer, B. Jermer, N. Asselin-Miller, S. Wessel, T. Patterson and J. Marcinkoski, J. Power Sources, 2014, 269, 975-993.

11 J. Wang, Energy, 2015, 80, 509-521.

12 US Department of Energy, Technical System Targets: Onboard Hydrogen Storage for Light-Duty Fuel Cell Vehicles, http:/www.energy.gov/sites/prod/files/2015/01/f19/fcto_ myrdd_table_onboard_h2_storage_systems_doe_targets_ ldv.pdf, accessed March 2016.

13 N. Guerrero Moreno, M. Cisneros Molina, D. Gervasio and J. F. Pérez Robles, Renewable Sustainable Energy Rev., 2015, 52, 897-906.

14 G. Øye, J. Sjöblomb and M. Stöckerc, Adv. Colloid Interface Sci., 2001, 89-90, 439-466.

15 Y.-P. Zhu and Z.-Y. Yuan, Mesoporous Organic-Inorganic Non-Siliceous Hybrid Materials, Springer-Verlag, Berlin, Heidelberg, 2015. 
16 N. Linares, A. M. Silvestre-Albero, E. Serrano, J. SilvestreAlbero and J. Garcia-Martinez, Chem. Soc. Rev., 2014, 43, 7681-7717.

17 S. P. Jiang, Solid State Ionics, 2014, 262, 307-312.

18 S. P. Jiang, J. Mater. Chem. A, 2014, 2, 7637-7655.

19 J. Zeng, B. He, K. Lamb, R. De Marco, P. K. Shen and S. P. Jiang, ACS Appl. Mater. Interfaces, 2013, 5, 1124011248.

20 J. Park and D. Kim, Int. J. Hydrogen Energy, 2014, 39, 1063-1070.

21 D. Schneider, D. Mehlhorn, P. Zeigermann, J. Karger and R. Valiullin, Chem. Soc. Rev., 2016, 45, 3439-3467.

22 J. Karger and R. Valiullin, Chem. Soc. Rev., 2013, 42, 41724197.

23 K. Vignarooban, J. Lin, A. Arvay, S. Kolli, I. Kruusenberg, K. Tammeveski, L. Munukutla and A. M. Kannan, Chin. J. Catal., 2015, 36, 458-472.

24 P. Zhang, H. Zhu and S. Dai, ChemCatChem, 2015, 7, 27882805.

25 P. Trogadas, V. Ramani, P. Strasser, T. F. Fuller and M.-O. Coppens, Angew. Chem., Int. Ed., 2016, 55, 122-148.

26 L. Dai, Y. Xue, L. Qu, H.-J. Choi and J.-B. Baek, Chem. Rev., 2015, 115, 4823-4892.

27 K. N. Wood, R. O'Hayre and S. Pylypenko, Energy Environ. Sci., 2014, 7, 1212-1249.

28 W. Li, J. Liu and D. Zhao, Nat. Rev. Mater., 2016, 1, 16023.

29 C. Zhong, W. B. Hu and Y. F. Cheng, J. Mater. Chem. A, 2013, 1, 3216-3238.

30 T. L. Lomocso and E. A. Baranova, Electrochim. Acta, 2011, 56, 8551-8558.

31 H. Li, H. Lin, Y. Hu, H. Li, P. Li and X. Zhou, J. Mater. Chem., 2011, 21, 18447-18453.

32 Y. Ma, R. Wang, H. Wang, V. Linkov and S. Ji, Phys. Chem. Chem. Phys., 2014, 16, 3593-3602.

33 L.-X. Ding, G.-R. Li, Z.-L. Wang, Z.-Q. Liu, H. Liu and Y.-X. Tong, Chem.-Eur. J., 2012, 18, 8386-8391.

34 E. A. Franceschini, G. A. Planes, F. J. Williams, G. J. A. A. Soler-Illia and H. R. Corti, J. Power Sources, 2011, 196, 1723-1729.

35 H. Wang, H. Y. Jeong, M. Imura, L. Wang, L. Radhakrishnan, N. Fujita, T. Castle, O. Terasaki and Y. Yamauchi, J. Am. Chem. Soc., 2011, 133, 14526-14529.

36 L. Wang and Y. Yamauchi, Chem.-Eur. J., 2011, 17, 88108815.

37 L.-X. Ding, G.-R. Li, Z.-L. Wang, Z.-Q. Liu, H. Liu and Y.-X. Tong, Chem.-Eur. J., 2012, 18, 8386-8391.

38 A. Serrà, E. Gómez and E. Vallés, Int. J. Hydrogen Energy, 2015, 40, 8062-8070.

39 A. Serrà, M. Montiel, E. Gómez and E. Vallés, Nano Mater., 2014, 4, 189.

40 J. Thepkaew, S. Therdthianwong, A. Therdthianwong, A. Kucernak and N. Wongyao, Int. J. Hydrogen Energy, 2013, 38, 9454-9463.

41 A. Takai, T. Saida, W. Sugimoto, L. Wang, Y. Yamauchi and K. Kuroda, Chem. Mater., 2009, 21, 3414-3423.

42 E. A. Franceschini, M. M. Bruno, F. J. Williams, F. A. Viva and H. R. Corti, ACS Appl. Mater. Interfaces, 2013, 5, 10437-10444.
43 E. Antolini, Appl. Catal., B, 2009, 88, 1-24.

44 H. Huang and X. Wang, J. Mater. Chem. A, 2014, 2, 62666291.

45 C. Galeano, J. C. Meier, M. Soorholtz, H. Bongard, C. Baldizzone, K. J. J. Mayrhofer and F. Schüth, ACS Catal., 2014, 4, 3856-3868.

46 X. Yuan, X.-L. Ding, C.-Y. Wang and Z.-F. Ma, Energy Environ. Sci., 2013, 6, 1105-1124.

47 D. Banham, F. Feng, T. Fürstenhaupt, K. Pei, S. Ye and V. Birss, J. Power Sources, 2011, 196, 5438-5445.

48 G. Sasikumar, J. W. Ihm and H. Ryu, Electrochim. Acta, 2004, 50, 601-605.

49 W. Zhang, J. Chen, G. F. Swiegers, Z.-F. Ma and G. G. Wallace, Nanoscale, 2010, 2, 282-286.

50 F. Han, X. Wang, J. Lian and Y. Wang, Carbon, 2012, 50, 5498-5504.

51 C. Zhang, L. Xu, N. Shan, T. Sun, J. Chen and Y. Yan, ACS Catal., 2014, 4, 1926-1930.

52 L. Zhao, Z.-B. Wang, X.-L. Sui and G.-P. Yin, J. Power Sources, 2014, 245, 637-643.

53 X. Li, W. Liu, J. Ma, Y. Wen and Z. Wu, Appl. Catal., B, 2015, 179, 239-248.

54 E. Li and V. Rudolph, Energy Fuels, 2008, 22, 145-149.

55 R. Ryoo, S. H. Joo and S. Jun, J. Phys. Chem. B, 1999, 103, 7743-7746.

56 K. L. Yeung and W. Han, Catal. Today, 2014, 236, 182-205.

57 X. He, Y. Zhang, C. Zhu, H. Huang, H. Hu, Y. Liu and Z. Kang, New J. Chem., 2015, 39, 8667-8672.

58 C.-Y. Ahn, J.-Y. Cheon, S.-H. Joo and J. Kim, J. Power Sources, 2013, 222, 477-482.

59 M. M. Bruno, M. A. Petruccelli, F. A. Viva and H. R. Corti, Int. J. Hydrogen Energy, 2013, 38, 4116-4123.

60 S.-Y. Lee, B.-J. Kim and S.-J. Park, Energy, 2014, 66, 70-76.

61 S. Pérez-Rodríguez, N. Rillo, M. J. Lázaro and E. Pastor, Appl. Catal., B, 2015, 163, 83-95.

62 C. A. Cao, X. Zhuang, Y. Su, Y. Zhang, F. Zhang, D. Wu and X. Feng, Polym. Chem., 2014, 5, 2057-2064.

63 M. Sevilla, L. Yu, T. P. Fellinger, A. B. Fuertes and M.-M. Titirici, RSC Adv., 2013, 3, 9904-9910.

64 R. Silva, D. Voiry, M. Chhowalla and T. Asefa, J. Am. Chem. Soc., 2013, 135, 7823-7826.

65 G. Wu, K. L. More, C. M. Johnston and P. Zelenay, Science, 2011, 332, 443-447.

66 L.-M. Zhang, Z.-B. Wang, J.-J. Zhang, X.-L. Sui, L. Zhao and D.-M. Gu, Carbon, 2015, 93, 1050-1058.

67 P. Song, L. Zhu, X. Bo, A. Wang, G. Wang and L. Guo, Electrochim. Acta, 2014, 127, 307-314.

68 K. Wang, Y. Wang, Z. Liang, Y. Liang, D. Wu, S. Song and P. Tsiakaras, Appl. Catal., B, 2014, 147, 518-525.

69 M. Lei, T. Z. Yang, W. J. Wang, K. Huang, R. Zhang, X. L. Fu, H. J. Yang, Y. G. Wang and W. H. Tang, Int. J. Hydrogen Energy, 2013, 38, 205-211.

70 X. Zhang, J. He, T. Wang, M. Liu, H. Xue and H. Guo, J. Mater. Chem. A, 2014, 2, 3072-3082.

71 M. A. Hoque, D. C. Higgins, F. M. Hassan, J.-Y. Choi, M. D. Pritzker and Z. Chen, Electrochim. Acta, 2014, 121, 421-427. 
72 M. P. Gurrola, M. Guerra-Balcázar, L. Álvarez-Contreras, R. Nava, J. Ledesma-García and L. G. Arriaga, J. Power Sources, 2013, 243, 826-830.

73 M. Yang, Z. Cui and F. J. DiSalvo, Phys. Chem. Chem. Phys., 2013, 15, 1088-1092.

74 M. Yang, R. Guarecuco and F. J. DiSalvo, Chem. Mater., 2013, 25, 1783-1787.

75 J. Zhang, Z. Xia and L. Dai, Sci. Adv., 2015, 1, e1500564.

76 P. Liu, J. Kong, Y. Liu, Q. Liu and H. Zhu, J. Power Sources, 2015, 278, 522-526.

77 F. A. Viva, M. M. Bruno, E. A. Franceschini, Y. R. J. Thomas, G. Ramos Sanchez, O. Solorza-Feria and H. R. Corti, Int. J. Hydrogen Energy, 2014, 39, 8821-8826.

78 D. J. You, X. Jin, J. H. Kim, S.-A. Jin, S. Lee, K. H. Choi, W. J. Baek, C. Pak and J. M. Kim, Int. J. Hydrogen Energy, 2015, 40, 12352-12361.

79 J.-M. Oh, J. Park, A. Kumbhar, D. Smith Jr and S. Creager, Electrochim. Acta, 2014, 138, 278-287.

80 M. Yang, Z. Cui and F. J. DiSalvo, Phys. Chem. Chem. Phys., 2013, 15, 7041-7044.

81 Z. Cui, R. G. Burns and F. J. DiSalvo, Chem. Mater., 2013, 25, 3782-3784.

82 A. H. A. Monteverde Videla, L. Zhang, J. Kim, J. Zeng, C. Francia, J. Zhang and S. Specchia, J. Appl. Electrochem., 2012, 43, 159-169.

83 L. Zhang, J. Kim, E. Dy, S. Ban, K.-c. Tsay, H. Kawai, Z. Shi and J. Zhang, Electrochim. Acta, 2013, 108, 814-819.

84 L. Zhang, J. Kim, E. Dy, S. Ban, K.-c. Tsay, H. Kawai, Z. Shi and J. Zhang, Electrochim. Acta, 2013, 108, 480-485.

85 H.-W. Liang, W. Wei, Z.-S. Wu, X. Feng and K. Müllen, J. Am. Chem. Soc., 2013, 135, 16002-16005.

86 M. E. Hamzehie, L. Samiee, M. Fattahi, A. A. Seifkordi, F. Shoghi and A. Maghsodi, Renewable Energy, 2015, 77, 558-570.

87 Y.-L. Liu, X.-Y. Xu, P.-C. Sun and T.-H. Chen, Int. J. Hydrogen Energy, 2015, 40, 4531-4539.

88 A. L. Ong, S. Saad, R. Lan, R. J. Goodfellow and S. W. Tao, J. Power Sources, 2011, 196, 8272-8279.

89 H. A. Gasteiger, A. Weber, K. Shinohara, H. Uchida, S. Mitsushima, T. J. Schmidt, S. R. Narayanan, V. Ramani, T. Fuller, M. Edmundson, P. Strasser, R. Mantz, J. Fenton, F. N. Buchi, D. C. Hansen, D. L. Jones, C. Coutanceau, K. SwiderLyons and K. A. Perry, Polymer Electrolyte Fuel Cells 13 (PEFC 13), The Electrochemical Society, Pennington, 2013.

90 J. R. Varcoe, P. Atanassov, D. R. Dekel, A. M. Herring, M. A. Hickner, P. A. Kohl, A. R. Kucernak, W. E. Mustain, K. Nijmeijer, K. Scott, T. Xu and L. Zhuang, Energy Environ. Sci., 2014, 7, 3135-3191.

91 R. Lan and S. W. Tao, Electrochem. Solid-State Lett., 2010, 13, B83-B86.

92 S. Lu, J. Pan, A. Huang, L. Zhuang and J. Lu, Proc. Natl. Acad. Sci. U. S. A., 2008, 105, 20611-20614.

93 J. Xiao, X. Bian, L. Liao, S. Zhang, C. Ji and B. Liu, ACS Appl. Mater. Interfaces, 2014, 6, 17654-17660.

94 H. Huang, Q. Wang, Q. Wei and Y. Huang, Int. J. Hydrogen Energy, 2015, 40, 6072-6084.
95 B. Chen, R. Li, G. Ma, X. Gou, Y. Zhu and Y. Xia, Nanoscale, 2015, 7, 20674-20684.

96 P. Ganesan, M. Prabu, J. Sanetuntikul and S. Shanmugam, ACS Catal., 2015, 5, 3625-3637.

97 X. Tong, X. Xia, C. Guo, Y. Zhang, J. Tu, H. J. Fan and X.-Y. Guo, J. Mater. Chem. A, 2015, 3, 18372-18379.

98 L. Lin, Q. Zhu and A.-W. Xu, J. Am. Chem. Soc., 2014, 136, 11027-11033.

99 X.-H. Yan and B.-Q. Xu, J. Mater. Chem. A, 2014, 2, 86178622.

100 J. Chen, X. Cui and W. Zheng, Catal. Commun., 2015, 60, 37-41.

101 D.-S. Yang, M. Y. Song, K. P. Singh and J.-S. Yu, Chem. Commun., 2015, 51, 2450-2453.

102 J. K. Dombrovskis, H. Y. Jeong, K. Fossum, O. Terasaki and A. E. C. Palmqvist, Chem. Mater., 2013, 25, 856-861.

103 R. L. Arechederra, K. Artyushkova, P. Atanassov and S. D. Minteer, ACS Appl. Mater. Interfaces, 2010, 2, 3295-3302.

104 Z. Chen, D. Higgins and Z. Chen, Carbon, 2010, 48, 30573065.

105 Y. Zheng, Y. Jiao, J. Chen, J. Liu, J. Liang, A. Du, W. Zhang, Z. Zhu, S. C. Smith, M. Jaroniec, G. Q. Lu and S. Z. Qiao, J. Am. Chem. Soc., 2011, 133, 20116-20119.

106 L. Qu, Y. Liu, J.-B. Baek and L. Dai, ACS Nano, 2010, 4, 13211326.

107 J. P. McClure, J. D. Thornton, R. Jiang, D. Chu, J. J. Cuomo and P. S. Fedkiw, J. Electrochem. Soc., 2012, 159, F733-F742.

108 S. Shrestha and W. E. Mustain, J. Electrochem. Soc., 2010, 157, B1665-B1672.

109 K. Wan, G.-F. Long, M.-Y. Liu, L. Du, Z.-X. Liang and P. Tsiakaras, Appl. Catal., B, 2015, 165, 566-571.

110 H. Zhang, Y. Zhou, C. Li, S. Chen, L. Liu, S. Liu, H. Yao and H. Hou, Carbon, 2015, 95, 388-395.

111 W.-J. Jiang, J.-S. Hu, X. Zhang, Y. Jiang, B.-B. Yu, Z.-D. Wei and L.-J. Wan, J. Mater. Chem. A, 2014, 2, 10154-10160.

112 J. Yan, H. Meng, F. Xie, X. Yuan, W. Yu, W. Lin, W. Ouyang and D. Yuan, J. Power Sources, 2014, 245, 772-778.

113 R. Wu, S. Chen, Y. Zhang, Y. Wang, W. Ding, L. Li, X. Qi, X. Shen and Z. Wei, J. Power Sources, 2015, 274, 645-650.

114 Q. Shi, Y. Lei, Y. Wang, H. Wang, L. Jiang, H. Yuan, D. Fang, B. Wang, N. Wu and Y. Gou, Curr. Appl. Phys., 2015, 15, 1606-1614.

115 J. Xu, Y. Zhao, C. Shen and L. Guan, ACS Appl. Mater. Interfaces, 2013, 5, 12594-12601.

116 S. Jiang, Y. Sun, H. Dai, J. Hu, P. Ni, Y. Wang and Z. Li, Electrochim. Acta, 2015, 174, 826-836.

117 J. Liang, Y. Jiao, M. Jaroniec and S. Z. Qiao, Angew. Chem., Int. Ed., 2012, 51, 11496-11500.

118 P. Xu, D. Wu, L. Wan, P. Hu and R. Liu, J. Colloid Interface Sci., 2014, 421, 160-164.

119 Z. Liu, H. Nie, Z. Yang, J. Zhang, Z. Jin, Y. Lu, Z. Xiao and S. Huang, Nanoscale, 2013, 5, 3283-3288.

120 V. Perazzolo, C. Durante, R. Pilot, A. Paduano, J. Zheng, G. A. Rizzi, A. Martucci, G. Granozzi and A. Gennaro, Carbon, 2015, 95, 949-963.

121 Y. Li, H. Zhang, Y. Wang, P. Liu, H. Yang, X. Yao, D. Wang, Z. Tang and H. Zhao, Energy Environ. Sci., 2014, 7, 3720-3726. 
122 S. Gao, X. Wei, H. Liu, K. Geng, H. Wang, H. Moehwald and D. Shchukin, J. Mater. Chem. A, 2015, 3, 23376-23384.

123 C. Alegre, M. E. Gálvez, R. Moliner, V. Baglio, A. S. Aricò and M. J. Lázaro, Appl. Catal., B, 2014, 147, 947-957.

124 M. M. Bruno, F. A. Viva, M. A. Petruccelli and H. R. Corti, J. Power Sources, 2015, 278, 458-463.

125 V. Rao, P. A. Simonov, E. R. Savinova, G. V. Plaksin, S. V. Cherepanova, G. N. Kryukova and U. Stimming, J. Power Sources, 2005, 145, 178-187.

126 J. B. Xu and T. S. Zhao, RSC Adv., 2013, 3, 16-24.
127 H. Chang, S. H. Joo and C. Pak, J. Mater. Chem., 2007, 17, 3078-3088.

128 J. Song, G. Li and J. Qiao, Electrochim. Acta, 2015, 177, 174180.

129 J. A. Herron, P. Ferrin and M. Mavrikakis, J. Phys. Chem. C, 2015, 119, 14692-14701.

130 L. A. Diaz and G. G. Botte, Electrochim. Acta, 2015, 179, 529537.

131 L. A. Diaz and G. G. Botte, Electrochim. Acta, 2015, 179, 519528. 